\title{
EL SISTEMA ESPAÑOL EN LA ÉPOCA DE LOS AUSTRIAS. EL MODELO POLÍTICO E INSTITUCIONAL (1516-1659)*
}

\author{
Juan E. Gelabert \\ Universidad de Cantabria
}

Resumen: Este artículo constituye el texto de una conferencia leída en la Fundación Duques de Soria en el verano de 1997. En él se sugieren algunas pautas de evolución del sistema político castellano desde el reinado de Carlos I hasta el fin de la hegemonía de la Casa de Austria (1659). Trata principalmente de los aspectos fiscales y administrativos que señalaron los principales períodos de la evolución arriba mencionada.

Palabras clave: Historia de Castilla, siglos XVI-XVII, historia fiscal, historia política, historia de la Administración, conflicto político.

Abstract: This article is the written version of a lecture delivered at the Fundación Duques de Soria in the summer of 1997. It contains some suggestions about the pattern of evolution of the Castilian political system from the reign of Charles I until the end of the House of Austria's hegemony (1659). It mainly deals with the fiscal and administrative aspects wich pointed at evolution above mentioned.

Key words: Castilian history, XVI-XVII Centuries, Fiscal history, Political history, Administrative history, Political conflict.

Parece que el triunfo de la candidatura de Carlos de Gante en la elección imperial de 1520 debió de significar en lo inmediato la necesidad de una readaptación del modelo político e institucional hasta entonces vigente en la Corona de Castilla. En parte así es. A la vuelta de Carlos, y en una década más o menos, fue tomando forma,

(*) El presente texto fue leído como conferencia en un ciclo que sobre la Monarquía Hispánica tuvo lugar en Soria en julio de 1987. Lo dirigió B. Bennassar y lo organizó la Fundación Duques de Soria. 
por ejemplo, un sistema consiliar que en buena parte de él levantaba acta de aquella realidad recién surgida ${ }^{1}$. El modelo institucional, pues, se alteró. Lo hizo en este tiempo, pero no es menos cierto que en el futuro apenas si volvió a tocarse en lo esencial. Respecto al modelo político, me atrevo a sugerir que el grado de modificación fue todavía menor. Si por esto se entiende, como creo que debe hacerse, la forma en la cual en un sistema de poderes se relacionaban los unos con los otros, la España de los Habsburgo constituyó en todo tiempo un paradigma de adecuación de este sistema a ciertos principios que desde 1516, como también anteriormente, todas las partes reconocían como inconmovibles. Se hablará de ellos. Baste decir ahora, a título de aclaración, que la proximidad cronológica entre el fecho imperial y la llamada Guerra de las Comunidades, ciertamente induce a pensar en una quiebra de estos principios directamente causada por éste, por el hecho imperial. Por el contrario, en mi opinión, cuando se repasan los acontecimientos que siguen a la muerte de Isabel I (1504), e incluso los de años inmediatos precedentes -no digamos los de la regencia de Cisneros- ${ }^{2}$, se obtiene la impresión de que lo que tiene lugar entonces no es sino un "ensayo general" de los acontecimientos de 1520-21. En otras palabras, y a reserva de insistir más adelante sobre ello, el proceder de Carlos y sus consejeros calienta una ya convulsa situación política que en 1520 , sencillamente, explota.

De un modelo institucional y de otro político habrá que dar cuenta. Permítaseme alterar los términos, poner delante el político, en la presunción de que éste habrá de ser el que configure aquél. Consiéntaseme, de igual modo, mostrar mi desafección con la expresión "modelo", que parece significar la singularidad que de lo uno y de lo otro tenía esta España de los Habsburgo, por encima de lo que creo que era una comunidad en lo político e institucional compartida con otras soberanías del llamado sistema europeo de estados.

Esta comunidad, en efecto, presentaba a mi juicio más elementos de similitud que de diversidad. En la mayoría de sus partes componentes era posible reconocer ciertos actores, como lo eran los príncipes, las aristocracias, las corporaciones urbanas. Por encima de todos, en calidad de poderes que llamaríamos "supranacionales", existían unos emperadores y un Imperio, como también unos papas y un Papado. En esta precisa esfera comenzaba la singularidad de Hispania, de la que podía predicarse una exemptio ab Imperii en virtud de su particular modo de acceso -la Reconquista- al escenario de aquellas soberanías. No era, sin embargo, única esta posición.

1 P. Fernández Albaladejo, Fragmentos de Monarquía, Madrid, 1992; pp. 88 y ss.

2 J. García Oro, El cardenal Cisneros. Vida y empresas, 2 vols., Madrid, 1992-3; especialmente I, cap. VIII. 
Por lo que a la Iglesia respecta, los años del acceso de Carlos I al trono de Castilla lo fueron también de revisión de las relaciones entre los príncipes y el Papado de Roma. Hubo aquí una vía media entre las soluciones galicana y anglicana, entre lo que significó para Francia el Concordato de Bolonia (1516) y para Inglaterra el Acta de Supremacía (1536). Impensable este último "modelo", el Regio Patronato negociado entre Carlos I y Adriano VI en 1523 no rompía, obviamente, pero tampoco puede decirse que fuera una "solución" que hubiera satisfecho en su tiempo al Emperador, cuanto menos a sus herederos. Abundan los testimonios relativos a la posición poco florida en la que quedaron los monarcas católicos frente a los reyes cristianísimos.

Pero las consecuencias hacia el futuro de esta limitada, limitadísima capacidad de control de los reyes de la Casa de Austria sobre el clero todavía estaban por ver. En apresurado resumen puede argumentarse que a partir de la conclusión del Concilio de Trento (1563) comenzaron a palparse los inconvenientes. La Iglesia Católica, que había permanecido como atada por sus propios problemas hasta entonces, buscó en adelante la definición de un espacio propio cuyos límites amenazaban con solaparse con los de los príncipes católicos. Este espacio propio lo definían sus derechos, prerrogativas e inmunidades; un conjunto de privilegia, un fuero que ubicaba al clero y a sus instituciones en una posición de indeseable libertad a los ojos de los príncipes seculares. El terreno en el que mejor, y más pronto, pudo palparse esta nueva posición fue el fiscal. Y, de nuevo, el contraste con lo que contemporáneamente sucedía en Francia (1563), da la medida de lo que Austrias y Valois estaban en condiciones de poder hacer o no. El clero, llegará a decirse en tiempo de Felipe IV, y con Urbano VIII en la cátedra de San Pedro, podía moverse "como si fuera súbdito de otro príncipe". El episodio (1631-2), sobre el cual habrá ocasión de volver, señaló, además, y como directa consecuencia, el momento de una toma de conciencia regalista hasta la fecha inédita ${ }^{3}$.

En el ámbito doméstico, de puertas adentro, un príncipe convivía, pues, como se ha dicho ya, con una aristocracia, unas corporaciones urbanas y una iglesia, esta última en muy particular posición que no conviene olvidar. De la aristocracia importará señalar inicialmente algunas obviedades, sobre todo en lo que hace al binomio monarcas-aristócratas. En ambos casos, para singularizarlas, hablamos de casas. No somos siempre conscientes de lo que estamos diciendo cuando nos referimos a la casa de Habsburgo, a la de Trastámara, pero también a la de Alba, a la de Medina Sidonia o a la de Lerma. Unas y otras son casas; unas y otras son la misma "cosa" hasta que una, tocada por la fortuna y el destino, viene a encarnar un poder superior, el real. Pues

${ }^{3}$ Q. Aldea, (S.J.), Iglesia y estado en la España del siglo XVII (ideario político-eclesiástico), Comillas, $1961 ; 3^{\text {a }}$ parte. 
bien: ni ésta se olvida de lo que fue, ni aquéllas se lo consienten. La expresión primus inter pares suele invocarse unilateralmente para hacer hincapié en el primus y obviar que los otros son pares. Es absurdo, así, aunque se ha hecho, plantear el desarrollo político del sistema de estados, global o aisladamente, recurriendo a una suerte de inexorable dialéctica entre monarquías y aristocracias. A mi entender resulta mucho más esclarecedor plantear el discurso en los términos arriba referidos; esto es, pensar en comunidad de intereses, en filiaciones, en colaboración, en flujos de derechos y deberes, de prestaciones y contraprestaciones.

La experiencia histórica del período Habsburgo camina por esta senda, salvo, quizá, durante -otra vez- los años de las Comunidades y, en alguna medida, el resto del reinado de Carlos I. Felipe II y sus sucesores sabían que en Murcia no se podía dar un paso sin contar con los Fajardo o en Guadalajara con los Mendoza; si había Cortes, la dirección de los votos de los cabildos era encomendada a los corregidores, pero también al conde de Alba de Aliste, al Condestable de Castilla o al Conde-Duque. A cambio de este apoyo a la casa real, los pares confiaban en ver confirmada su autoridad sobre sus vasallos, extender sus señoríos, obtener mercedes, etc.

En fin, las corporaciones urbanas tuvieron en el desarrollo histórico del período que nos ocupa una significación que en las últimas dos décadas ha servido para catapultarlas a primera fila en la atención de los historiadores. También aquí convienen algunas iniciales aclaraciones. Hablamos de villas y ciudades dotadas de una panoplia de sucesivos y acumulativos privilegios, comenzando por el fuero, que rodean el principio originario de su autogobierno. Sirven a los príncipes y se relacionan con ellos de forma similar a como lo hacen los señores de vasallos. Más allá de un prurito protocolario obtendrán, como ellos, el título de señorías. Pero su vinculación con los príncipes es sin duda mayor; o mejor que con los príncipes, con la corona que cada uno de ellos sucesivamente porte. Con ésta comparten una misma sustancia, su carácter corporativo; en 1442 acabarán entendiendo que la mejor garantía de su perpetuidad consistirá en vincular su fortuna a la de aquella corona ${ }^{4}$. Su devenir, pues, en buena medida habrá de fluctuar al ritmo que sacuda a la monarquía.

Príncipes, ciudades, aristócratas se conjugan para formar desde Aristóteles otros tantos sistemas políticos que, vulgarizados por Tomás de Aquino, aquí y allá responden a monarquías, timocracias (o democracias) y aristocracias. Difícilmente se cuestiona la idoneidad de las primeras; con todo, se admite también que el ideal es una casi imposible- síntesis de las tres, habida cuenta de que individualmente consideradas

${ }^{4}$ J.A. Pardos Martínez, "Comunidad, persona invisibilis" en la miscelánea -junto con P. Fernández Albaladejo- "Castilla, territorio sin Cortes (siglos XV-XVII)", Revista de las Cortes Generales, 15 (1988); pp. 113-208. 
ni cada una es por sí ideal ni totalmente deshauciable. El ideal de una "república mixta" aparecerá en más de un autor. Permítaseme, sin embargo, ahora mencionar que Francisco de Vitoria creyó que la Castilla de sus días, la de después de las Comunidades, disponía de una "constitución mixta"5; o que una República Mixta (1602) constituía tanto el ideal pretendido como la evidencia observada por Juan Fernández de Medrano. Sea como fuere, lo que con la caracterización de "mixta" quería significarse era que a juicio de los observadores aquella realidad política había logrado alcanzar un grado de acuerdo, de cohesión entre sus partes, que la hacía próxima al ideal arriba mencionado. La Castilla del tiempo de los Habsburgo no era la "sociedad conflictiva" que alguno ha predicado. Es más: ni de la observación de su devenir histórico, ni relativamente a lo que aconteció en otras monarquías de su tiempo tiene sentido postular tal caracterización ${ }^{6}$. El único conflicto digno de tal nombre, el de las Comunidades, tal vez sirvió, justamente, para que en lo sucesivo cada uno hiciera memoria de su papel, y no tratara de inmiscuirse en el de otros.

¿Y cuáles eran estos papeles? Parece obvio comenzar por aclarar el del príncipe. Pocos textos más expresivos a este respecto que el de las Cortes de Ocaña de 14697:

[...] el ofiçio del rey, así por su primera invençión como por su nonbre, es regir, y hase de entender, bien regir; porque el rey que mal rige, no rige, más disipa. Siguese que, pues, quitar e determinar qüistiones y dar a cada uno lo suyo es ofiçio de rey; e este tal exerciçio se llama justiçia [...] e por el exerciçio de aquesta prometió Dios, por boca de su Propheta, a los reyes perpetuidad de su poder; primero, y en persona de aquesta tan poderosa e virtuosa virtud, dezía el Sabio: "por mi los reyes reinan". E pues, muy poderoso Sennor, si por ésta los reyes reinan, conclúyese que vos, que sois rey, para hazer ésta reinais; y así bien se puede afirmar que vuestra dignidad real cargo tiene, e a cargoso trabajo es subjeta. E vuestro cargo es, que mientras vuestros súbditos duermen Vuestra Alteza vele guardándolos. Y su meresçenario sois, pues soldada desto vos dan vuestros súbditos, parte de sus frutos e de las ganançias de su industria, y vos sirven con sus personas muy ahincadamente a los tienpos de vuestras nesçesidades, por vos hazer mas poderoso, para que relevedes las suyas e quiteis sus vexaçiones.

Pues mire Vuestra Alteza si es obligado por contrato callado a los tener y mantener en justiçia, [...] e joya es la justiçia que no la fía sino de sus amigos o a lo menos de los executores de su voluntad [...].

Pero, porque la carga del juzgado es grande y el que tiene el çetro de la justiçia ha menester quien le ayude, fue nesçesario que el rey buscase ministros de la

${ }^{5}$ F. de Vitoria, Political Writings, eds. por A. Pagden y Lawrance, Cambridge, 1991; p. XIX.

${ }^{6}$ Los "conflictos populares" de los siglos XVI y XVII objeto de una reciente monografía (P. L. Lorenzo Cadarso, Los conflictos populares en Castilla (siglos XVI-XVII), Madrid, 1996), constituyen peleas de patio de colegio si uno tiene la precaución de elevar ligeramente el punto de mira.

${ }^{7}$ A. García-Gallo, Manual de Historia del Derecho Español, 8 a ed., Madrid, 1979; II, p. 815. 
justiçia inferiores a él, entre los quales repartiese sus cargos, quedando para él la jurisdiçión soberana [...] a los quales pusieron nombre oidores, por enxenplo de aquellos que en el Sacro palaçio apostólico oyen e determinan las causas; y del ayuntamiento destos se halló el nombre de Audiencia, la qual después de su fundamento bien se muestra ser casa de justiçia que la Sabiduría edificó sobre las siete colupnas que ella cortó, según dize el Sabio. Y es de creer que esta Audiençia fue fundada sobre piedra firme, pues conbatida y lonbardeada por algunas nigligençias o injustiçias de los reyes sus fundadores, e por ministros idiotas o maliçiosos, e por denegamiento de sus estipendios e por aborresçimiento e menospreçio de la justiçia, nunca del todo se ha podido perder, en tanto que, a lo menos, aunque sin tejado e sin paredes, siempre paresçen ende los fundamentos, conbidando a Vuestra Alteza de cada día a la reedificación dellos. [...]

Zele y ame, pues, Vuestra Alteza la justicia, porque si esta ama será cierto que oirá quando más menester le fuere lo que dizía el Profeta: "amaste la justiçia e aborreçiste la maldad, por eso te ungió Dios, etc."

No podrá argumentarse que es éste un testimonio extemporáneo si a continuación se aclara que una poco elegante versión del mismo fue precisamente la que escuchó Carlos V en las Cortes de Valladolid de $1518^{8}$. Parece obvio, por tanto, que entonces como ahora, ellos y nosotros, lo consideremos como un texto de alto valor pedagógico: en 1518 había que enseñarle a un rey bisoño cuáles eran sus deberes. Los castellanos se los conocían tan bien que ni necesidad tenían de tenerlo puesto por escrito: se trataba de un "contrato callado".

El primero, y no sólo por orden, sino el fundamental de aquellos deberes, habría de ser el de regir bien. Este ejercicio, a su vez, comprendía otros dos, a saber, el de la justicia conmutativa y el de la distributiva ("quitar e determinar qüistiones" y "dar a cada uno lo suyo"). Por este trabajoso oficio recibe el príncipe soldada, de ahí el calificativo de mercenario. Vale la pena detenerse aquí. Tiene, en efecto, el príncipe originariamente otorgados por sus súbditos unos bienes, unos recursos con los que ha de desenvolverse para cumplir con su oficio. Son éstos determinados derechos, indisputables, que genéricamente conocemos con el nombre de regalías fiscales. En Castilla lo son, entre otros, las aduanas, los derechos por acuñación de moneda, las salinas, y -para algunos- también las alcabalas. Se admite que han de ser suficientes para cumplir con ese oficio, esto es, administrar justicia y defender a sus súbditos. Esto y no más. Lo cual quiere decir que otros compromisos al margen de los referidos al reino no interesan, sobre todo si de su ejecución ha de derivarse un esfuerzo fiscal suplementario. Este, en principio, pues, era algo indeseable, algo que no entraba en el "contrato". ¿Lo entendía así el joven Carlos? Casi seguro que no si nos atenemos a la segunda parte del texto, allí donde se desarrolla el asunto de la administración de la justicia.

8 J. Perez, La révolution des “Comunidades” de Castille (1520-1521), Burdeos, 1970; pp. 126-7. 
Esta "joya" no es objeto que pueda dejarse en manos de cualquiera. Para su administración necesita el príncipe gentes de confianza, amigos, que oigan lo que los súbditos tengan a bien solicitar en audiencia. Nadie mejor que algunos de éstos para "repartir" entre ellos los oficios de oidores 9 . En 1518 parece claro que el rey no oye bien. La audiencia está como cortocircuitada. Hay "nigligençias" e "injustiçias”, ¿tal vez causadas por "ministros idiotas o maliçiosos"?. Es muy posible, habida cuenta del entourage con el cual Carlos se ha dotado.

Se acumulan, pues, varios argumentos de conflicto, básicamente que el rey no puede oír porque los ministros no son los a propósito, y que los dineros de los súbditos se están empleando para tareas que no corresponden al oficio de rey. La injusticia está servida.

Una guerra fue precisa para que Carlos aprendiera la lección. ¿Cómo se restauró la confianza? Hubo que atender, primero, a las audiencias y a sus ministros. Audiencias ya había, ciertamente, y por encima de ellas un Consejo llamado en ocasiones, muy propiamente, de la Justicia. No es casual que los comuneros se refirieran a él como "el mal Consejo". Este fue "visitado" personalmente por Carlos; salió Rojas y entró Tavera; no casualmente este último procedía de la Chancillería de Valladolid, la única audiencia que mereció algún respeto a los comuneros. "En años sucesivos anota el mejor conocedor de la institución- la organización y la actividad del Consejo Real siguieron con bastante fidelidad los derroteros marcados por los Reyes Católi-

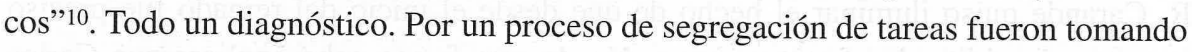
cuerpo otros consejos. Naciendo de donde lo hacían, respetando aquellos derroteros en lo que tocaba a las personas que habrían de ir ocupándolos -"perlados", "doctores", la monarquía de Carlos fue dotándose de un perfil que los castellanos empezaban ya a reconocer.

Siguieron haciéndolo cuando hubo que empezar a hablar de los inevitables dineros. No se ponía en cuestión lo que a su majestad correspondía por su "oficio"; más allá comenzaba el problema. Los historiadores parecen haber pasado como sobre ascuas sobre la circunstancia de la indefinición en la que a estos efectos se hallaba la alcabala, justamente la mejor "joya" de la corona fiscal de los reyes de Castilla. Basta leer el testamento de Isabel para percatarse de que si la reina albergaba dudas sobre su carácter regaliano ${ }^{11}$, qué no pasaría por la cabeza de los contribuyentes. Con todo, desde el fin de la guerra de Granada parece que pudo alcanzarse un cierto consenso

9 Sobre oídos y audiencias véase B. Clavero, "Sevilla, concejo y audiencia: invitación a sus ordenanzas de justicia", que sirve de introducción a las Ordenanzas de la Real Audiencia de Sevilla, Sevilla, 1995; pp. 9-95.

${ }^{10}$ S. de Dios, Fuentes para el estudio del Consejo Real de Castilla, Salamanca, 1986; p. XXVI.

11 A. de la Torre y del Cerro, Testamento de la reina doña Isabel la Católica, Valladolid, 1968. 
sobre la base de que ni la monarquía parecía estar dispuesta a prescindir de ella, ni el reino a que se cobrase sin las debidas garantías. Como las que estaban en disputa eran precisamente las de orden jurídico, no era fácil dar solución al tema. Se halló, sin embargo. Dado que tampoco parece que fuera intención del reino dejar a su rey en la indigencia, ambas partes soslayaron el punto en litigio, el carácter regaliano, y conversaron sobre cuantías y modos de percepción. Así, poco a poco, paso a paso, ciudad tras ciudad, fueron suscribiéndose contratos bilaterales llamados de encabezamiento. Tan fructífera resultó la experiencia que en 1504 Isabel dejó dicho que si la alcabala debía cobrarse, sería precisamente de este modo, como forma más suave de exacción. Lo aceptaron sus sucesores, y sólo Carlos se atrevió a violarlo. Poniendo las alcabalas en arrendamiento, como hizo desde Barcelona al decidir su candidatura al Imperio, rompía unilateralmente los contratos, e incluso lo que él mismo hasta la fecha había dado por bueno. Recuérdese que su marcha atrás en este punto contribuyó a mejorar el ambiente en favor de su propia causa en el verano de 1520.

Pero era obvio que ni siquiera con las alcabalas podía su majestad sustentarse. En caso de apuro financiero, podía solicitarse el auxilium del reino, demandándolo en Cortes, bajo la forma de servicio. Así lo hizo Carlos, en las cuantías que venían siendo habituales, sólo que con una regularidad -trienal- milimétrica, dictada por sus propias necesidades, que sus antecesores, menos necesitados, a veces se saltaron -para bien del reino. Aun así, el foso entre ingresos y gastos era "crónico", expresión con la que R. Carande quiso iluminar el hecho de que desde el inicio del reinado fue preciso inventar el crédito, los famosos juros. No de otra forma cabe explicar que Carlos pudiera hacer lo que hizo con unos ingresos que en términos reales, ajustados al curso de los precios, crecieron en su tiempo tan sólo un $1 \%$. Esta deuda, y éstos sus titulares, acabarían por convertirse en una de las más sólidas apoyaturas del "sistemà".

El buen entendimiento de Carlos con la Castilla post-comunera encontró aquí uno de sus mejores argumentos. La regularidad con la que las Cortes hubieron de ser convocadas, no inferior a su permanente presencia en la corte por medio de su Diputación $(1525)^{13}$, constituyó, sin duda, otro de los factores que convirtieron a Castilla en un país políticamente estable, casi monótono, para el resto del reinado. Y ello a pesar de las ausencias de Carlos, sabiamente neutralizadas también mediante el recurso a una casa en la que siempre pudieron hallarse relevistas.

Con quien parece que Carlos no logró entenderse del todo bien fue con la aristocracia castellana. El primer encontronazo, nunca superado, tuvo lugar a propósito

12 Ch. D. Hendricks, Charles V and the "Cortes" of Castile. Politics in Renaissance Spain, Ann Arbor (Mi), 1976; p. 270.

13 J. I. Fortea Pérez, "Trayectoria de la Diputación de las Cortes", Las Cortes de Castilla y León en la Edad Moderna, Salamanca, 1989; pp. 33-87. 
del nombramiento de Adriano como regente, un lugar que los grandes creían suyo. Se conoce también que a partir de este hecho los grandes dejaron hacer a la Comunidad, afirmando incluso que lo que ésta hacía era a su entender "en servicio de Dios y bien de estos Reinos". Se callaron cuando le tocó a dos ellos lidiar con la revuelta. Sin embargo, Carlos hizo mal pago de sus servicios; por razones que ni mucho menos están claras, la aristocracia fue sonoramente lateralizada a su vuelta. No es cabal explicación la que imputaría esta maniobra a un exceso de compromiso con las ciudades de Castilla; para unas y otra había sitio, tal y como sus abuelos practicaron, por lo menos hasta el fin de la guerra de Granada. Tal vez tenga algo más de sentido hacer la observación de que en el servicio al Emperador, uno de los cometidos seguramente más apetecidos por los grandes, éstos hubieron de competir con sus pares de otras provincias y partes del Imperio.

Sea como fuere, la ruptura quedó definitivamente sancionada en las cortes de Toledo de 1538. El tono de algunas declaraciones, amén de mostrar no poca envidia hacia la posición alcanzada por los procuradores de las ciudades, muestra además la desconfianza de la nobleza hacia los planes carolinos. En las últimas escenas del drama el fantasma de las Comunidades volvió a aparecer en boca, obviamente, de los grandes, lo que causó la práctica expulsión de éstos de la reunión.

Los resquemores permanecieron para volver a aflorar cuando la situación así lo permitió. Me refiero a los años, meses incluso, inmediatamente precedentes al definitivo asentamiento de Felipe II en Castilla. El tono general de la situación lo pintó $\mathrm{F}$. Braudel hace años: "L'alerte protestante", "Le malaise politique", "Les difficultés financières"14... Más recientemente M.J. Rodríguez-Salgado ha podido titular su análisis del mismo período con esta sorprendente etiqueta: "Rebellion in the Spanish Realms"15. En este sentido, y que yo sepa, nadie ha perseguido una pista alumbrada por F. Braudel que hace precisamente referencia a un protagonismo de los grandes en esta crisis que valdría la pena conocer más a fondo. Me refiero al memorial que un licenciado Palomares elevó a Felipe II dándole cuenta de que tanto ahora (1559) como ya antes (1548-50), en ambos casos aprovechando tanto sus ausencias como las de su padre, hubo reuniones de grandes en Valladolid "au sujet des prétentions excessives des grands seigneurs en matière judiciaire". El memorial de Palomares no contiene nimiedades ${ }^{16}$. Los grandes, "en ofensa de la autoridad rreal", querían por ejemplo que "solamente fuese su juez V.M." y no sus ministros, audiencias y chancillerías; querían

${ }^{14}$ F. Braudel, La Méditerranée et le monde méditerraneen à l'époque de Philip II, Paris, 1966; II, pp. 268 y ss.

${ }^{15}$ M.J, Rodríguez-Salgado, The Changing Face of Empire. Charles V, Philip II and Habsburg Authority, Cambridge, 1988; pp. 253 y ss. Hay traducción al castellano.

${ }^{16}$ AGS, E, leg. 137. 
también "cédula general" que garantizase el uso de las alcabalas para todo aquéllos que las tenían sin título, y que merecían -las alcabalas- el título -bien expresivo- de "alcabalas de inocencia", "de tolerancia" o "de permisión". Pero la fronda nobiliar apuntaba todavía más alto. Los grandes convocados en Valladolid querían para sí "cámara" a la que aplicar las condenaciones de los pleitos que llegaban en apelación a los "tribunales mayores" (Chancillerías y Audiencias). Palomares advertía "para su cámara que llaman, porque no tienen cámara ni se auía de llamar sino solamente cámara de V.M.”. ¿Y qué significaba esto?. Movámonos cuarenta años adelante, hasta la Política de don Gerónimo Castillo de Bovadilla. Aquí encontraremos que:

Los Duques, Condes, y Marqueses, y los otros Señores de vasallos destos Reynos, son en sus estados y tierras, Vicarios de los Reyes y Corregidores perpetuos, obligados a la observancia de las leyes Reales, y de los capítulos de Corregidores, y equipáranse en algunas cosas a los Príncipes y Reyes, y pueden llamarse Señores de sus villas, y en ellas sin incurrir la pena de la nueva premática de las cortesías, y luego diremos la razón deste nombre Señor ${ }^{17}$.

"Equipáranse en algunas cosas", se nos ha dicho. De qué "cosas" sean éstas, las que aproximen o distinguan, se trata también. Aproxima, en concreto, que príncipes y señores puedan tener "cámara" o "cámara y fisco", asunto éste que a Palomares no hace ninguna gracia, y que ciertamente era objeto de disputa ${ }^{18}$. En la práctica los señores "aplicaban" en ciertos casos, no todos, si bien, como se ha dicho, cabía duda y faltaba reconocimiento explícito de estos atributos de la soberanía a los señores. Lo dice don Gerónimo:

pueden los Señores de vassallos, y sus Juezes condenar en las penas y calumnias de desprezes y omezillos, y en otras pecuniarias, y aplicarlas a su cámara y fisco, como los Reyes y sus Juezes, aunque no pueden confiscar bienes ${ }^{19}$.

Palomares es menos condescendiente. Pensar que los señores puedan tener cámara y fisco es "muy gran perjuizio a la juridiçión suprema de V.M.", y aún aconseja: "no consienta [V.M. ] hazer nobedad".

Pero aún había más puntos en el "programa" de los grandes. Tocaba ahora el turno al ejercicio de la justicia, a la del rey y a la de los señores, y hasta dónde llegaba

17 G. Castillo de Bovadilla, Política para corregidores y señores de vasallos en tiempo de paz y de guerra, I, p. 445; cito por la ed. facs. Madrid, 1978.

18 B. Clavero, "Hispanus Fiscus, Persona Ficta: concepción del sujeto político en la época barroca", Tantas personas como estados. Por una antropología política de la historia europea, Madrid, 1986, pp. 53-105.

${ }^{19}$ G. Castillo de Bovadilla, Política..., I, p. 458. 
cada una. Casi nada. El asunto en litigio era la famosa ley de Guadalajara de 1390. Dejaré que hable Palomares que lo contará mejor que yo:

Ansimismo V.M. sabrá que el rrey don Juan el primero, aviendo alteraçiones en estos Reynos, dizen que hizo una ley en Guadalajara que conçedía y otorgaua a los caualleros que tienen vasallos y lugares que pudiesen apelar y apelasen de las sentençias que diesen sus alcaldes para ante los señores, la qual no está ynpresa ni puesta por ley en ningunos libros de molde, y V.M. no consienta ni permita se ponga ni scriua por ley.

Su modo de entender el asunto era claro. La ley no estaba escrita, algo que en 1597 reconocía también don Gerónimo Castillo de Bovadilla (“consta [sólo] por su corónica"), y en derecho era insostenible: no podía apelarse de un tribunal ante el mismo, salvo en el caso de la jurisdición real, "porque todas las jurisdiciones residen en el Príncipe, y del emanan y proceden como de fuente, y a él mismo tornan y se debuelven" (Gerónimo Castillo de Bovadilla). Caso de aceptarse que el circuito sentencia-apelación pudiera cerrarse dentro del señorío, su titular quedaría equiparado en "superioridad" al príncipe, pues superioridad era precisamente la audiencia en grado de apelación. Pero esto, seguía Palomares, era pura y simplemente intolerable; esta segunda audiencia era propia de un ejercicio que se hacía "no reconociendo superioridad a otro rrey ni enperador, y los grandes destos rreynos y caualleros son vasallos de V.M. y no, huelga decirlo, otros tales reyes o emperadores".

Ahora bien. Los grandes actuaban en este caso espoleados por una práctica que paradójicamente nacía en uno de los consejos de su majestad, el de Hacienda. Palomares cuenta que últimamente, en las cartas de venta de lugares que a la sazón se practicaban, uno de los compradores, licenciado Juan de Vargas, había solicitado -y obtenido- la inclusión de los supuestos de apelación en su título, proceder que siguieron los demás adquirentes, con gran escándalo de los grandes que creían tenerlo reservado. Éstos, en suma, se habían congregado, ahora por segunda vez, para obtener ley en su exclusivo favor, lo que da pie a pensar que de hecho este circuito de sentenciaapelación ya funcionaba. Confirmación de que, en efecto, debía ser así la proporciona don Gerónimo. Tras consignar la duda y diversidad de opiniones entre los doctores (Palacios Rubios, Covarrubias, etc.) concluye:

sería duro de sustentar [que no se debe guardar], porque desde que se promulgó, se introduxo y aprehendió tanto por los Señores de vasallos, como cosa tan favorable a ellos (entre otras razones, por provarse el Señorío y jurisdición por el juzgar en secunda instancia) que assí por la costumbre casi universal, como por los autores destos Reynos, que passan con ella, está en muchas partes observada ${ }^{20}$.

${ }^{20}$ G. Castillo de Bovadilla, Política..., I, pp. 460-1. 
Felipe II heredó, pues, un país convulso. Desconocemos casi todo de estos primeros años de su reinado en lo que toca a temas que no sean la política fiscal y la religiosa. Con todo, un rostro de aparente tranquilidad interior parece haberse inaugurado a partir de entonces, sólo salpicado ya por los efectos domésticos de aquella política fiscal. En efecto, es sabido que la imposibilidad de atajar el déficit financiero desde el momento en el que la revuelta de Flandes cercenó cualquier posibilidad de alivio, creó numerosas tensiones sociales y políticas por mor del fiscalismo al que se vio abocada la administración hacendística. De lo que en las Cortes pasó ha dado cumplida cuenta J.I. Fortea Pérez ${ }^{21}$. También sabemos algo del descontento social que provocaron ciertos arbitrios, de los que el rey podía valerse ya que se trataba de formas de captación de recursos basadas en el tráfico de sus regalías, pero cuyo mero uso caía en el ámbito de la duda jurídica sobre su licitud, amén de plantear problemas morales, sociales y políticos entre los individuos o comunidades afectadas. De todo esto último sólo podían las Cortes protestar, contradecir en algún caso, ajeno como era a las tradicionales formas de auxilium que aquéllas tenían por objeto de su convocatoria.

Estaba sucediendo que a pesar del incremento (un 37\%) en el precio del encabezamiento general de las alcabalas pactado a partir de 1562, y de la creciente aportación del tesoro de Indias, todo se antojaba poco para atender como era preciso a los frentes militares abiertos. Tan así era que en 1575, al tiempo que volvía a declararse una nueva suspensión de consignaciones, el encabezamiento general volvía a experimentar una dramática elevación (300\%, esta vez), y el recurso a los arbitrios entraba en un período de frenética actividad, de la que no serían relevados hasta los primeros años del reinado de Felipe III. ¿De qué se trataba?. Los oficiales del Consejo de Hacienda vendían tierras baldías (también llamadas de realengo), oficios municipales, hidalguías, privilegios de villazgo, vasallos, etc. Casi sin excepción, todos estos expedientes afectaban muy directamente a las corporaciones urbanas, ya fuese desde el punto de vista del status personal de sus individuos, del propio gobierno municipal, o de su integridad jurisdiccional o territorial.

En diversas ocasiones procedió Felipe II a vender tierras baldías. Podía hacerlo, cuestión que conviene aclarar, habida cuenta de que más de uno ha hablado de asalto a la "propiedad" municipal. No es exactamente así. Su majestad vendía lo que era suyo, si bien los pueblos disfrutaban de ello. Suya era también la facultad de crear o suprimir oficios. En las creaciones, los principales perjudicados eran los viejos titulares que veían súbitamente incrementada la nómina de sus pares y por ende disminuida su autoridad. Si lo que se decidía era ofrecer a su majestad el valor del oficio para

21 J.I. Fortea Pérez, Monarquía y Cortes en la Corona de Castilla. Las ciudades ante la política fiscal de Felipe II, Salamanca, 1990. 
impedir su creación, los arbitrios usados al efecto tenían también efecto negativo, aunque esta vez sobre las bolsas del común. También era indisputable su derecho a hacer hidalgo a un plebeyo, por mucho que las Cortes protestaran y la opinión otorgara en exclusiva a la sangre garantía de continuidad en el estado de los individuos.

Mucho mayor problema jurídico representaban las llamadas ventas de vasallos y los privilegios de villazgo. Estos últimos, de los que también había usado Carlos I, consistían en la erección de villas a partir de lo que en otro tiempo habían sido aldeas dependientes del señorío de una villa o ciudad. Desde varios puntos de vista el arbitrio en cuestión era más que indeseable, amén de jurídicamente reprochable. En primer lugar, la referida ley-pacto de 1442 había sancionado la entrada de ciudades y villas en el patrimonio de la Corona, convirtiéndolas así en parte del mayorazgo del reino, por lo tanto indisponible. De aquella forma, las ciudades habían intentado poner freno a la desmembración de su patrimonio en favor de la nobleza. Lo que jamás se les pasó por la cabeza es que Carlos se saltara lo entonces dispuesto y partir de 1537 hubiera comenzado a desmembrar él mismo aquel patrimonio. Pudo ponerse pronto freno al arbitrio, pues en las Cortes de Toledo de 1538-9 el Emperador aceptó no volver a las andadas a cambio de un cuantioso servicio. El respeto a los términos del contrato, pues no de otra cosa se trataba, duró hasta 1554. Argumentó entonces Carlos que el acuerdo sólo vinculaba a las ciudades de voto en Cortes, al tiempo que tanto su hijo como el Consejo Real le recordaban que era su obligación mantener la palabra dada. Pero en 1556 fue el propio Felipe quien no quiso saber nada de lo acordado por su padre, reiniciándose así el proceso. Las ciudades protestaron con fuerza. Algunas de ellas (Córdoba, Toledo, Sevilla) podían aducir, además, que al lado de las condiciones del servicio de 1538-9, existían "asientos" previos al acuerdo general en los cuales las ciudades habían puesto miles de ducados para garantizarse que en lo sucesivo no volvería a tener lugar tan indeseable expediente. Como última garantía, el juramento de Felipe II como rey incluía la expresa cláusula de no volver a usar de él.

Todo fue en vano, y el malestar de las villas y ciudades del reino fue creciendo de tono a medida que se acercaba el fin del reinado. Respecto a las ventas de vasallos, en realidad ventas de la jurisdicción sobre sujetos del realengo o recién incorporados a él previa evicción del señorío eclesiástico, los efectos eran, para las ciudades, prácticamente los mismos, sólo que ahora el nuevo amo solía ser un señor particular, mientras que en el caso anterior lo era un concejo.

Las actas de las Cortes de 1592-8 deben ser leídas con estos presupuestos a la vista. Más otros que tampoco conviene olvidar. Me refiero a las solicitudes de auxilium que a partir de 1590 conocemos con el nombre de servicios de millones. Tras el primero (1590-5), y una vez que pasaron a mejor vida los intentos de imponer un "medio", como el de la harina, al que se tenía por panacea de todas las desgracias fis- 
cales y financieras del tiempo, Felipe II no encontró mejor expediente que tratar de repetir la edición del de 1590-5. La oposición de las Cortes fue sutil, pero dura. Con altísimos costes sociales y económicos para los pueblos se habían levantado los ocho millones de ducados, y la impresión era que aquel esfuerzo no había servido absolutamente para nada. El reino no parecía, pues, estar dispuesto a repetir, sin más, la experiencia. Quería hacer salir al rey del hoyo de la deuda, “desempeñarle”, para que sus rentas bastasen a los fines que tradicionalmente tenía encomendados. No obstante, un halo de desconfianza podía percibirse respecto a lo que el rey haría con el dinero del reino si éste, finalmente, aceptaba volver a servirle. Ya en 1590 la palabra condiciones había aparecido tímidamente. Ahora sería la estrella del discurso. El reino estaba dispuesto a ofrecer su ayuda pero no alegremente; quería garantías del buen uso de sus dineros; también evitar que los denostados arbitrios volvieran a correr. Todo fue cuidadosamente, pesadamente anotado en una escritura, en un contrato. Este contenía capítulos que obviamente no gustaron a Felipe II; algunos los consideraba atentatorios contra la dignidad real y una seria hipoteca en su capacidad de acción fiscal así como en la de sus herederos. El Rey Prudente se fue a la tumba sin haber aceptado los términos de la escritura. La herencia que dejaba a su heredero puede imaginarse si añade que dos años antes se había visto obligado a declarar otra bancarrota.

Pero no era éste el único contratiempo de los años finales de su reinado. El régimen felipista adolecía en los últimos años 80 y siguientes de ciertos malestares de profunda y ulterior significación. Como resultado de la lucha faccional de décadas previas y de su precario estado de salud, Felipe II formalizó en 1585 una Junta de Gobierno, mejor conocida por su posterior etiqueta: la Junta de Noche ${ }^{22}$. La Junta tenía el propósito de evitar la dispersión de la atención del rey hacia todos y cada uno de los consejos. Ahora bien, en lógica reacción, éstos tendían por su parte a actuar sin esperar órdenes; y se les hacía difícil reconocer la autoridad de una Junta a la que identificaban no con la persona del rey sino con las de unos cuantos "favoritos" como Moura, Idiáquez, Chinchón, etc. En particular don Cristóbal de Moura fue capaz de concentrar en torno a sí tanto poder de decisión que la filiación de su figura con la del duque de Lerma no resulta en modo alguno exagerada.

Hubo, pues, juntas y validos en los años finales del reinado de Felipe II, y por supuesto también las consabidas críticas a un gobierno "ignorante y confuso", tal y como lo calificaba Íñigo Ibáñez de Santa Cruz, entre otros. Añádase, ya en las postrimerías del reinado, la polémica reforma del Consejo de Castilla ${ }^{23}$, sobre la base de una

${ }_{22}^{2}$ A. Feros Carrasco, The King's Favorite, The Duke of Lerma: Power, wealth and Court Culture in the Reign of Philip III of Spain, 1598-1621, Tesis doctoral (inédita), Johns Hopkins University, 1994, pp. 44 y ss.

${ }^{23}$ S. de Dios, Fuentes...; pp. XXXVII y ss. 
impronta gubernativa que llegará a provocar la dimisión del presidente Vázquez de Arce, y sin duda también la conmoción en el "gobierno de los jueces".

Lo referido apunta a la aparición entonces de síntomas de "desequilibrio" en la cúspide, con inequívoca repercusión hacia la comunidad política en general, los cuales valdría la pena tratar con mayor profundidad y detenimiento. Atiéndase, por ejemplo, a lo que las Cortes denuncian en uno de los varios capítulos de las de 1592-824. En primer lugar, la desviación experimentada por el sistema consiliar en favor de las juntas. Quien no fuera advertido de la fecha de este documento lo tomaría por posterior en unos veinte, treinta o cuarenta años, esto es, más propio del juntismo lermista u olivarista que de un inédito "felipista":

[...] ha parecido [a las Cortes] suplicar a V.M. muy humildemente, sea servido de mandar que todos los negocios que ocurrieren en estos sus Reynos y los demás de su Real corona, se vean, resuelvan, traten y despachen en los consejos y tribunales que con tan gran prudencia y consideración V.M. y los Señores Reyes sus predecesores acordaron oviese en su Real corte, de Estado, de Guerra, Justicia y Gracia, y otros; pues no parece se puede ofrecer caso que no toque a uno de los dichos Consejos, y hacer juntas particulares sacando los negocios de su centro, y Consejos que tan santamente y con tanto acuerdo y deliberación están señalados, y dedicación para ellos, y donde se platican y ven con particular distinción, por mayor y menor, los proes y contras que los negocios tienen, no parece que conviene.

Tal modo de llevar los asuntos no es propio -añaden- del "buen gobierno". A mayores se nos informa también de que ya que no todos los ministros reales son llamados a las juntas, las exclusiones generan malestar ("sentimiento") "viendo que se meten personas más nuevas, y no de la experiencia y noticias de aquellas cosas". Si fuere deseo de su majestad favorecerles -siguen perorando- "se tendría por menor inconveniente que V.M. los desviase con hacerles merced, o en otra manera, y no que acusen novedades, e introducciones tan perjudiciales, acarreadas sólo por fines y respetos particulares, contrarios totalmente al bien público, en que deve hacer merced V.M. a estos sus Reynos de mirar mucho". Y se concluye:

pues como es notorio, sin estas Juntas se han gobernado y mantenido en mucha paz, justicia y buen gobierno [...]; y quando ya fuese necesario que con los de un Consejo concurran otros, que estos tales mande V.M. vayan al dicho Consejo de donde es el negocio, y en él se trate y resuelba lo que convenga, y ofreciéndose caso tan extraordinario de hacer una Junta, que a lo menos pasen los negocios si son de Estado ante el Secretario de Estado, y si de Guerra, ante el de Guerra, y no ante otro, y así ante los demás Ministros, porque con esto los negocios tendrán dueño propio para que se hagan y despachen, y quando se quiera saver lo que se acordó, se halle, por lo mucho que esto importa, y no sacar los negocios de su curso y corriente.

${ }^{24}$ Actas de las Cortes de Castilla...; XI, pp. 502-4. 
Recuérdese, en fin, que la aprobación del servicio de millones en 1590 había tenido no poca dosis de resistencia, con pasquines y carteles alusivos esparcidos por las ciudades (Ávila, Madrid), llegando a provocar por último lo que jamás había acontecido en Castilla desde las Comunidades: la condena a muerte de dos regidores abulenses, de los cuales uno fue efectivamente ejecutado.

Caliente estaba, pues, el reino de Castilla en los días del acceso de Felipe III. La inquietud podía percibirse entre el pueblo llano, sufridor, además, por aquellos días de la horrible epidemia de peste con la llegaba el nuevo siglo; no le iba a la zaga el descontento entre los notables de las ciudades, muy molestos por los arbitrios (ventas de oficios, singularmente) que últimamente se habían acumulado; y, por último, tampoco el "estado real" pasaba en aquellos días, como se ha visto, por sus mejores momentos. Sin embargo, todo nuevo régimen político parece disponer de un capital inicial, de un período de confianza sostenido por la común creencia en la mejora de la situación. No fue excepción el de Felipe III, sobre todo por la mala imagen de los últimos años del de su padre.

¿Con qué problemas se enfrentaban rey y reino en los últimos meses de 1598 ? Los del uno eran, ciertamente, también los del otro. Las imágenes organológicas a las que tan aficionados eran nuestros antepasados, servían ahora a las mil maravillas para dar a entender que los males del país, del "cuerpo" político, no hallarían solución a no ser que ésta lo fuera in caput et in membris. Con seguridad que lo primero que Lerma y Felipe III tratarían de enmendar iba a ser la situación financiera, pues como razonaban desde el Consejo de Estado "sin Hacienda no pueda haber Stado". La herencia era dramática. La bancarrota de 1596 y el medio general que la siguió extinguieron por completo las rentas ordinarias de la monarquía, salvo el tesoro de Indias. Sin embargo, tanto éste como las rentas extraordinarias quedaron igualmente hipotecadas en dicho medio general, en satisfacción de la deuda y a cambio de algunas provisiones para los meses inmediatos. Felipe III no tenía, pues, un solo marevedí disponible por muchos días.

Apenas si las Cortes tuvieron descanso con motivo de la transición. No obstante, lo que pudiera dar de sí su generosidad no era tema que fuera a liquidarse en unas pocas semanas. Y Felipe III no podía esperar, ya que inicialmente la tarjeta de presentación del régimen consistió en tratar de liquidar por la vía de las armas los conflictos (Inglaterra, Provincias Unidas) que el Rey Prudente había sido incapaz de concluir. Hacía falta dinero, mucho dinero. Desesperado, no quedó a su majestad más remedio que decretar en 1599 la emisión de monedas de cobre puro, maniobra complementada por otras similares en 1602 y $1603^{25}$. Extraordinarias como estas medidas eran, no

${ }^{25}$ E. J. Hamilton, American Treasure and the Price Revolution in Spain, 1501-1650, Nueva York, 1970 (reimpr.); pp. 75-6. 
podía basarse en ellas ninguna suerte de arreglo perdurable. El acuerdo con el reino para alcanzar de él alguna ayuda seguía siendo imprescindible.

Las posiciones estaban sin embargo muy alejadas. El rey y sus ministros circulaban por la vía de la búsqueda de arbitrios, esto es, de más recursos. El reino argumentaba que los ordinarios eran suficientes, pero que lo que había que hacer era "desempeñarlos". Ésta había sido la estrategia del fallido servicio de los 500 cuentos, y al poco los ministros reales decidieron que no les quedaba más remedio que proseguirla. En los días de la Navidad de 1600, tras dos años de negociación, podía anunciarse un acuerdo que empezaría a ser efectivo al año siguiente. Era un servicio de 18 millones de ducados, a razón de tres anuales durante seis, con inequívoca intención de desempeño. En pocas palabras, el reino se hacía cargo de la deuda con los banqueros, y su majestad debía destinar los recursos así liberados al ansiado desempeño. Para pagar a los banqueros, el reino consentía en imponer una sisa sobre el vino. Los cálculos previamente hechos garantizaban sobre el papel que $1 / 8$ de sisa era suficiente para alcanzar una recaudación de 3 millones de ducados anuales.

La operación era compleja, con enorme grado de compromiso para ambas partes; el rey debía emplear sus recursos en desempeñarse y el reino alcanzar lo suficiente como para pagarle sus deudas. Ni lo uno ni lo otro se cumplió; ni la sisa rendía, ni su majestad respetaba lo pactado. Del desempeño no parecía que nadie se acordase ya. Sin embargo existía una Junta que atendía a tal apelativo, y que empezó bien pronto a erigirse como uno de los símbolos más indeseables del régimen lermista ${ }^{26}$. Tan torpes fueron sus manejos con el dinero, sus corruptelas, que puede aseverarse que, de hecho, actuó como detonante de la puesta en cuestión del valimiento de Lerma en fecha tan temprana como 1606. Sus tres principales cabezas (Pedro Álvarez Pereira, Pedro Franqueza y Alonso Ramírez de Prado) fueron procesados. Como advierte A. Feros, la denuncia no tocaba tanto a su escandaloso enriquecimiento individual, etc., como al uso de prácticas político-administrativas (las juntas, por ejemplo) tanto o más escandaloso a juicio de los acusadores que la malversación de fondos. Compárese el texto antes transcrito con lo que sigue procedente de los "cargos" contra Pedro Franqueza:

estando dispuesto por leyes y ordenanzas reales de gobierno y jurisdicción del Consejo de Hacienda y Contadurías como neçesaria para su beneficio [...], pareçe haber defraudado a su Real Hazienda de todo, porque el dicho Consejo y Contadurías y la substancia a que se reducen [...], la incorporó en la dicha Junta ${ }^{27}$.

26 J. M. Pelorson, "Para una reinterpretación de la Junta de Desempeño General (1603-1606) a la luz de la 'visita' de Alonso Ramírez de Prado y Pedro Franqueza, conde de Villalonga", Actas del IV Symposium de Historia de la Administración, Madrid, 1983, pp. 613-27.

${ }_{27}$ A. Feros Carrasco, Gobierno de Corte y Patronazgo Real en el Reinado de Felipe III, Memoria de Licenciatura (inédita), Universidad Autónoma de Madrid 1986, p. 108. 
Es decir: el fraude no estaba tanto en llevarse los dineros a la bolsa propia, como en usar de vías incorrectas para hacerlo.

Pero por si esto fuera poco, no sólo el plan de desempeño había fracasado, no sólo los ministros eran unos corruptos material y formalmente, sino que a menos de una década de su entrada en el valimiento debía encarar el valido la responsabilidad de una bancarrota (1607). Los años 1607-9 fueron cruciales para el desenvolvimiento del régimen lermista. La solución de la bancarrota, primero, significó la alienación del interesado apoyo que hasta la fecha habían dispensado al régimen las oligarquías urbanas; un apoyo, hay que decirlo, con sabrosas contrapartidas que vale la pena reseñar ahora.

El servicio de los 18 millones se instrumentó con medios, las sisas, cuya incidencia sobre estos sectores se conocía que era mínima. En otros términos: los oligarcas de las ciudades sentados en las Cortes traspasaron a otros hombros, los de los consumidores, el peso del compromiso fiscal que habían asumido. Pero no terminó aquí su modus operandi. A cambio de la operación de desempeño en la que se metían, exigieron de su majestad el cese de las más sangrantes -para ellos- aristas de la política de arbitrios hasta entonces vigente. En efecto, lo que en la escritura de 1601 eran condiciones, como la definitiva suspensión de la venta de oficios, en 1602 y 1608 aparecían como leyes que pueden verse en la Recopilación ${ }^{28}$. Su majestad, en suma, quedaba privado de recurrir a éstos y a otros, y sometido ahora y en lo porvenir a lo que las Cortes tuvieran a bien ofrecerle, en cantidad y calidad.

Felipe III y su valido parecieron querer vengarse en 1608. Ya que ni la Junta del Desempeño ni la escritura del servicio de millones habían servido al fin propuesto, ¿por qué no encargarle la tarea a los genoveses?. Es conocida la pésima opinión que en Castilla había contra ellos. Iba sin embargo a crecer, arrastrando con ella a Lerma y a sus hechuras. La cuestión era tan simple como lo que sigue. Puesto que se había decretado poco antes que en lo sucesivo no habría nuevos juros por encima del $5 \%$, la llamada Diputación del Medio General compraba -redimía- primero los viejos, y si el jurista quería seguir manteniendo su renta venía obligado a aumentar su capital. Este "caudal" pagaba la deuda de los banqueros, con lo cual los juristas, a la postre, se convertían en forzados deudores de los compromisos de su rey.

El malestar fue imaginable 29 . Para echar más leña al fuego aparecía entonces en Colonia (1609) lo que vertido al castellano, y manuscrito, había producido Juan de Mariana con el título de Tratado y discurso sobre la moneda de vellón que al presente

${ }^{28}$ Leyes XXV, XXVI, XXVIII, XXIX y XXX, tít. III, lib. V, las tocantes a oficios municipales.

29 I. Pulido Bueno, La real hacienda de Felipe III, Huelva, 1996, cap. X. 
se labra en Castilla y de algunos desórdenes y abusos ${ }^{30}$. Más allá de la precisa denuncia sobre el arbitrio del vellón, Mariana se empleaba a fondo contra todos los agentes de la vida política, sin exceptuar la propia majestad real. Tal y como rezaba el escrito de acusación, el Tratado constituía tema de "gran desacato de la Persona Real y del Estado de estos reinos y gobierno y ministros de ellos" 31 . No quedaba, en efecto, títere con cabeza. Transcribo lo dedicado a los procuradores de Cortes:

en Castilla poco aprovecha llamar a Cortes los procuradores de las ciudades. Los más de ellos son poco idóneos para tales negocios, sacados por suertes, hombres livianos y de inclinación vendible, sin tener delante de los ojos otra cosa más que deseo de ganar la gracia del rey con el daño público y de ella sacar provecho para sí.

Existían sin embargo argumentos de más calado, como lo era -nada menos- el negar de raíz la legalidad del arbitrio del vellón. Para ello Mariana demostraba primero que el arbitrio era tributo; a continuación que era nuevo tributo; y concluía por fin que tanto las leyes del reino como la bula In Coena Domini convertían en tirano al príncipe que impusiera tributo sin consentimiento. El Tratado, a modo de resumen, constituía una de las más furibundas invectivas contra un régimen político que jamás hayan podido leerse. Del juicio sobre la situación actual se pasaba a la predicción más negra:

Todo lo que cada provincia está corrompida, mezclados los vicios de todas, ha pasado a las costumbres de España, de manera que parece que la fortuna, precipitada de lo alto, amenaza graves desgracias y ellas ya instan. El Imperio que ganó la virtud lo pierde la opulencia y los deleites que vienen con ella; el vigor de los ánimos con que llegaron a consumarse las cosas de la guerra y de la paz, la licencia de los vicios los ha acabado porque nada hay que tanto daño haga al ejercicio militar. Este ha sido el fruto de las victorias de los enemigos, ampliar el reino por tierra larguísimamente y por el mar, que el término de la tierra y del cielo lo es suyo. Caemos a ejemplo de los romanos con intervalo de menos tiempo que ellos, cuya caída se causó de haber propagado el Imperio a Asia y pasado a Roma los instrumentos y regalos de los deleites.

En este sentido, la firma de la Tregua de los Doce Años con las Provincias Unidas pareció a los sectores anti-lermistas como una claudicación. De hecho la crisis del régimen seguía avanzando, y hoy sabemos que el llamado decreto de delegación de firma (1612), más que significar la cota suprema del valimiento del favorito, consti-

${ }^{30}$ Puede verse en ed. de L. Beltrán, Madrid, 1987.

31 G. Fernández de la Mora, "El proceso contra el padre Mariana", Revista de Estudios Políticos, 79 (1993), pp. 47-99. 
tuyó un agarradero a la desesperada ${ }^{32}$. La paz instalada en 1609, que podía haber significado una situación óptima para asentar desde ella la ansiada reformación que el país demandaba, pasó de largo ante los ojos de Lerma y sus ministros, quienes incluso se vieron obligados a solicitar del reino un segundo servicio de millones (1608) a razón de 2.5 anuales, con el cual, de nuevo, volvió a intentarse el desempeño. Era inútil si el régimen no manifestaba intención de reforma, como de hecho sucedía. En otro lugar he podido demostrar que a partir de 1609 , y a pesar de que el mantenimiento económico de la reputación no era ni mucho menos baladí, existió margen suficiente para que finalmente los problemas financieros del reino encontraran mejor acomodo ${ }^{33}$. Gentes había también dentro del propio sistema que creían que entonces era posible no sólo atender a los gastos que se presentaban sino también hacer ahorros de cara al futuro, en vista de la eventual llegada de peores tiempos. Quizás como un síntoma más de la desconfianza que existía en el destino al que iban finalmente los dineros, en 1611 las Cortes obtenían para sí la administración de su propio esfuerzo, mediante la erección entonces de una diputación, más conocida como Comisión de Millones.

Los malos tiempos, lamentablemente, llegaron. Los preludios que venían anunciando la confrontación en tierras de Imperio finalmente se precipitaron en 1618. José Alcalá-Zamora observó hace ya años cómo en los meses antecedentes habían llegado a la corte toda una serie de nuevos actores cuya sintonía con Lerma sencillamente era inexistente ${ }^{34}$. Le arrollaron. A su frente estaba don Baltasar de Zúñiga.

El nuevo régimen trató de enmendar muchas de las corruptelas del pasado. La conciencia de que había llegado el momento de la reformación, dio como resultado la creación de la célebre Junta y al poco el diseño de un "programa" cuya discusión, materialización y espíritu llegarían incluso a los primeros años del reinado de Felipe IV. Para salir del paso, de momento, las Cortes fueron convocadas y en 1619 aprobaban un tercer servicio de millones del que el ideal del desempeño había desaparecido por completo. Como alternativa, el reino creaba su propia bolsa y atendía con ella a los gastos que consideraba inabdicables, a saber, la defensa del reino y la administración de la justicia. Paradójicamente, hacía así el reino tareas de rey, mientras éste empleaba lo poco que tenía en las empresas dinásticas.

A la involucración en el Imperio siguió, como es sabido, la reanudación de la guerra con las Provincias Unidas (1621). La Monarquía Hispana volvía, pues, a la senda belicista, en pos del mantenimiento de una supremacía en el sistema europeo de

${ }^{32}$ A. Feros Carrasco, Gobierno de Corte.., pp. 111-2.

33 J. E. Gelabert, La bolsa del rey. Rey, reino y fisco en Castilla, 1598-1648, Barcelona, 1997, pp. 51-3.

34 J. Alcalá-Zamora y Queipo de Llano, España, Flandes y el mar del norte, 1638-1639, Barcelona, 1975. 
estados que acabaría por hundirla. En el aspecto doméstico, el equipo comandado por Zúñiga, a cuya sombra ya se movía don Gaspar de Guzmán, comenzó por liquidar políticamente el pasado. Lo hizo en varios frentes. Lo más llamativo era sin duda actuar sobre las personas, y en este sentido el proceso contra don Rodrigo Calderón constituyó un indicador de por donde no se volvería a andar. Hacía décadas que no pasaba por el verdugo un ministro de su talla; las razones para llevarlo al cadalso eran muchas, si bien ante la opinión pública contaba sobre todas el castigo a las prácticas corruptas en el manejo de los dineros. De hacer caso al inventario de sus bienes confeccionado con ocasión del proceso, Calderón poseía propiedades que alcanzaban los dos millones de ducados. Para tener una idea de lo que esos millones significaban bastará decir que esa era justamente la contribución anual del reino en el servicio de millones aprobado en 1619.

Una política radicalmente distinta quería para sí el régimen de Felipe IV en el inicio de su reinado. A la ejecución de don Rodrigo Calderón siguió la declaración por la que también se cortó el flujo de mercedes de hacienda ${ }^{35}$. Al poco se conocía también el famoso decreto de 14 de enero de 1622, por el que todos los oficiales reales venían obligados a declarar sus propiedades y rentas ${ }^{36}$. Y si el fisco del rey daba señales de tener que apretarse el cinturón, la universal reducción del tipo de interés de los juros al 5\% significa el traslado forzoso de esta misma política al resto de los vasallos. Finalmente, en febrero de 1623 se publicaban los capítulos surgidos de la Junta Grande de Reformación. Interesará ahora decir respecto a ellos que significaban un intento de radical alteración de los usos político-administrativos más indeseables del gobierno anterior; en especial, se ponía el énfasis en el papel de los consejos como únicas instancias susceptibles de entrar en el gobierno de la monarquía, y se denunciaba, para condenarlo, el recurso a las jurisdicciones comisariales que solían acompañar al proceder de las juntas. No cabía otra forma de gobernar la cosa pública que no fuera a través de los consejos. En el Gran Memorial de 1624, Olivares tomaba el curso más tradicional a estos efectos al consignar que eran "miembros" de todo un "cuerpo" cuya "cabeza" era su majestad.

Sin embargo, la entrada en los conflictos de 1618 y 1621 iba a someter al régimen a presiones difícilmente imaginables por sus neófitos responsables. Felipe III había dejado no sólo la bolsa exhausta, sino además empeñada. Como en 1598, el recurso a la labor del vellón facilitó la transición. Pero Olivares quería bases financieras más firmes. La Junta de Reformación se había hecho eco del llamado "plan de los

35 J. H. Elliott y J. F. de la Peña, Memoriales y cartas del conde duque de Olivares, 2 vols., Madrid, 1978-81; I (Política interior: 1621 a 1627), pp. 3 y ss. ("Memorial sobre las mercedes").

36 J.F. de la Peña, Oligarquía y propiedad en Nueva España, 1550-1624, México, 1983, pp. 13-4. 
erarios" que como serpiente de verano venía apareciendo desde los tiempos de Felipe II. Ahora el valido pretendía su realización. Para su puesta en marcha era necesario algún capital inicial, a cuyo efecto los ministros reales querían exigir el 5\% (la "veintena") de todos aquellos que tuvieran capital por encima de 1.000 ducados. En realidad, esos ducados no irían directamente a la bolsa del rey, sino a los bancos, para redituar en ellos un $3 \%$ anual; se decía por ello que los titulares de los dineros de hecho no contribuían sino que "trasladaban el empleo" de sus riquezas. La oposición al plan sin embargo no se hizo esperar. Es posible identificar, al menos, dos frentes de oposición. Por supuesto el de los previsibles afectados, a los que no hacía ninguna gracia que alguien dictara el mejor empleo de sus dineros, a saber, los poderosos de las ciudades que a través de sus cabildos dijeron no sistemáticamente a los planes de Olivares ${ }^{37}$. El segundo, más inquisitivo, más profundo, más político, cabe identificarlo con la oposición del clero, igualmente afectado en principio. Aquí se argumentaba que ${ }^{38}$ :

en la materia de que se habla tienen obligación los Reyes de oyr lo que se les aduierte, y lo que más es, que Vuestra Magestad la tiene en conciencia de consultarlo con el Reyno, y aun en la parte que toca a los tributos, no hazer nada sin su consentimiento.

Esto mismo lo pensaban sin duda los laicos, si bien públicamente no se atrevían a tanto, o aducían razones de menor calibre. Sin embargo los eclesiásticos tomaban la voz de todos:

esto es lo que oy haze con Vuestra Magestad y con vuestros ministros por todo este Pueblo el estado Eclesiástico: dar consejo y oponerse a la resolución de Vuestra Magestad que juzga dañosa.

Y la razón era bien simple: el tributo puesto sin consentimiento se volvía injusto y hacía al rey tirano. En la línea de Juan de Mariana, no cabía ni siquiera pedir el consentimiento de las Cortes, ya que de los procuradores "todo el mundo piensa que en estos casos más atienden a su interés que al bien público, pues nadie ignora que los Presidentes, y ministros grandes, a quien tocan estos despachos, se veen forzados a reduzirlo con ellos a trato; y assí el pueblo reconoce que todo esto se ha hecho venal".

Se equivocaba el P. Balboa, autor del escrito, respecto a las Cortes, que acabarían diciendo sí, a condición de que los erarios se instrumentasen con hacienda del rey, lo cual era condenarlos al fracaso. Ahora bien, lo que desde luego merece ser desta-

37 F. Ruiz Martín, “La banca en España hasta 1782”, El Banco de España. Una historia económica, Madrid, 1970, pp. 62 y ss.

${ }^{38}$ A.H.N., Inquisición, 4.467. 
cado, y no será ésta la última vez, es el papel director, pastoreador, que en materia de tributos se atribuían los curas, y hasta cierto punto la Iglesia entera. Adviértase que para el caso no sólo se ponía en cuestión la capacidad real para imponer sobre el estamento eclesiástico, sino que también ciertos sectores clericales se permitían denunciar la sede (las Cortes) desde la que su majestad obtenía el consentimiento, para trasladarla a otra, informal, sin concretar, y restringida a una opinión, a un consejo que apelaba directamente a la conciencia de la persona real.

Oposición clerical y en los cabildos urbanos eran argumentos más que suficientes para forzar a Olivares a dejar que las Cortes idearan la mejor manera de ayudar a su rey. Poco antes, sin embargo, el ramalazo autoritario del conde-duque le condujo a buscar opiniones que pudieran haber facilitado la puesta en vigor de los erarios. Sabemos poco de la junta que a tal efecto se formó en 1624; sí de lo que habría de dictaminar, a saber, "si de poder absoluto lo podía [el rey] pedir [el auxilio del reino], y para adelante, quitando los Procuradores, y que las ciudades no tuviesen que confirmar lo que el Consejo de Estado mandase, por cuya materia de Estado se gobierna la Monarquía"39. El parecer de la Junta fue negativo; no podían quitárseles a las ciudades sus "estatutos y costumbres", y por consiguiente no había otro camino sino el de las Cortes.

Estas, finalmente (1626), acordaron agregar otros 2 millones de ducados durante 6 a los otros 2 que estaban a punto de concluir (concedidos en 1619). Era demasiado tarde. Se habían hecho esfuerzos enormes para sacar adelante el annus mirabilis (1625), y los banqueros no podían seguir haciendo asientos sobre la base de consignaciones de cada vez más lejana fecha. Como además surgieron nuevos y graves compromisos (guerra de Mantua), no quedó más remedio que decretar una bancarrota en noviembre de 1627.

Fueron los meses posteriores al decreto de intensa reflexión sobre el futuro político de la Monarquía. No faltaron, por ejemplo, voces que reclamaron la conveniencia de liberarse de alguno de los frentes de guerra (Flandes), so pena de hundir al país en una carrera de exigencias fiscales cuyo fin difícilmente podía preverse. Tal y como había sucedido en fecha no menos crucial (1618), una Junta Grande fue convocada para alumbrar soluciones. No es extraño que para Matías de Novoa mereciera el título de "junta prodigiosa", ya que alguna de las propuestas que de ella salieron olían a pura fantasía ${ }^{40}$. La que finalmente se adoptó -el “crecimiento" de la sal- no era sólo un arbi-

${ }^{39}$ A. de Almansa y Mendoza, Cartas de A. De Almansa y Mendoza. Novedades de esta corte y avisos recibidos de otras partes, 1621-1626, Madrid, 1886, pp. 295-6.

40 J.H. Elliott, The Count-Duke of Olivares. The Statesman in an Age of Decline, New Haven-Londres, 1986, pp. 415-8. Hay traducción al castellano. 
trio más. Visto en su conjunto, esto es, a tenor de sus consecuencias inmediatas, significó una de las más severas convulsiones políticas en las que se encontró inmersa la monarquía a lo largo del siglo XVII. Sin embargo, apenas si ha merecido la atención de los historiadores en los últimos tiempos.

Debe insistirse en que aquéllo no era un arbitrio más. Había materia fiscal, pero también política e institucional, si es que cada una de ellas puede -o debe- tomarse aisladamente. Lo que los ministros reales pretendían sacar adelante era, a mi entender, un nuevo escenario de relaciones entre el rey y el reino junto en cortes mediante el sencillo expediente de liquidar este último. No era la primera vez que se intentaba; ahora, sin embargo, el plan parecía estar mejor preparado. El auxilium del reino, imprescindible para el desarrollo de la política dinástica concebida por el Consejo de Estado, ni de lejos alcanzaba lo que nominalmente valía ${ }^{41}$. Pero el colmo era que condicionase además el despliegue de la política de arbitrios y otros aspectos no menos importantes del ejercicio de la autoridad real. Si pudiera prešcindirse del auxilium del reino, se decía, habría de ser a cambio de algún medio que garantizase no sólo iguales o mayores rendimientos, sino también una más justa distribución de la carga fiscal. Pero prescindir de esta ayuda tenía ulteriores lecturas. Significaba, también, prescindir de las Cortes, de la sede que aprobaba y administraba aquélla, y bajo cuya responsabilidad caía el actual estado -lamentable- financiero de rey y reino.

Nadie podía discutir a su majestad el uso y disfrute de sus regalías fiscales, y por aquí justamente se encaminaron los pasos. La atención se puso en la sal, la cual sería estancada primero y vendida después merced a todo un nuevo entramado administrativo bajo la autoridad de un Consejo de la Sal. A su vez, el reino sería dividido en provincias al cargo de un "protector", y puesto que urgía la rápida ejecución del proyecto se arbitraban dos sistemas de cobro; a saber, o bien los pueblos iban adquiriendo en los alfolíes la cantidad de sal que necesitaban -y a este fin se confeccionó el censo de 1631- o bien serían obligados a "acopiarse". Todo parecía liso y llano sobre el papel, aunque en las reuniones que en 1630 tuvieron lugar para examinar pros y contras, ya se vieron no pocos, previsibles contratiempos. De orden técnico eran aquéllos que veían el asunto como muy aventurado, pudiendo ser resumidos en la opinión de que "más valía lo corto pero cierto de los millones que lo incierto aunque grueso de la sal". Pero los de orden político y jurídico eran de mayor enjundia.

Las regalías fiscales, como lo era la sal, no deberían conocer exenciones estamentales en su percepción; y así como clérigos e hidalgos debían pagar alcabala, del mismo modo pagarían el "crecimiento". En similar línea argumental se decía que tam-

${ }^{41}$ J.I. Andrés Ucendo, "El servicio de millones durante el siglo XVII", Hacienda Pública Española, 134 (1995), passim. 
poco cabrían exenciones territoriales, teniéndose presente la eventual cobranza en las provincias de "gobierno más privilegiado", esto es, el reino de Navarra y las provincias Vascongadas. Se lograría así descargar el peso de la presión fiscal sobre Castilla. Ahora bien, ¿podía, sin más, su majestad decretar la abolición de los millones y anunciar la introducción de la gabela sobre la sal?. Más de uno entre los presentes creía que no. Los servicios de millones constituían un contrato, la ruptura unilateral no parecía políticamente aconsejable. Podía disolverse en Cortes, donde había sido pactado, si bien el propio Felipe IV tenía esta precisa convocatoria como muy peligrosa, razonando que no vendrían en ello por la mucha cuenta que les traía el actual sistema. Alguien aconsejó que debería por lo menos "comunicarse".

Existían también inconvenientes dogmático-políticos. La sal venía vendiéndose a un precio "natural.", "justo", fruto de la "apreciación", de la oferta y de la demanda; distinto, en fin, según provincias. Pero para lograr los 4 millones de ducados de los servicios en vigor era necesario aumentar el precio, y unificarlo además. La resultante era que éste, el precio, dejaba entonces de ser "natural", "justo"; lo que se incrementaba pasaba a ser, el exceso, tributo descarado, el cual su majestad imponía -o pretendía imponer- sin consentimiento. Y esto, como la "veintena" de 1623 o el arbitrio del vellón de 1599, era tiranía en opinión de alguno de los convocados, no siendo necesario, pues, que alguien desde fuera y a posteriori viniese a recordarlo.

Quien leyere los pareceres emitidos por la junta concluiría que era una temeridad echar a andar el "crecimiento". Sin embargo se hizo. "En 30 de junio se pregonó que el rey quitaba desde 1 de julio los Millones", consignan unos anales de Sevilla ${ }^{42}$. En efecto, se anularon los vigentes dos servicios de millones, y comenzó a correr la gabela sobre la sal. Pero el resultado fue absolutamente decepcionante en términos recaudatorios, y peligrosísimo en lo político. Todo se conjuró para hacer de lo acontecido en estos años 1631-2 uno de los más graves momentos del siglo en Castilla.

Las condiciones socio-económicas fueron de lo más inoportuno. Vicente Pérez Moreda ha señalado la gravedad de lo sucedido en el bienio 1631-2: problemas de subsistencia, mortalidad, etc. ${ }^{43}$ Esta situación trajo consigo la material imposibilidad de que los pueblos pudieran pagar, a la fuerza o de grado,las cantidades de sal que estaban previstas. El elevado precio, por otra parte, generaba corrientes de contrabando que de igual modo tiraban a la baja del rendimiento de la gabela.

Lo dicho no era nada en comparación con la oposición política que el arbitrio generó. Ésta se concentró en dos frentes; dos frentes que ponían de manifiesto la

42 Memorias de Sevilla (1600-1678), ed. de F. Morales Padrón, Córdoba, 1981, p. 68.

${ }^{43}$ V. Pérez Moreda, Las crisis de mortalidad en la España interior (siglos XVI-XIX), Madrid, 1980, pp. 109-11. 
defensa que de sus privilegios estaban dispuestos a hacer por una parte el clero, y por la otra aquellas provincias de "gobierno más privilegiado" como eran las Vascongadas. En Madrid la preocupación fue sin comparación infinitamente mayor a propósito de la oposición clerical. El esquema era el siguiente: el clero sevillano, su cabildo, sus portavoces, opinaban que siendo ellos estamento exento no deberían ser incluidos en el "crecimiento", aun cuando éste lo fuera de carácter regaliano. El uso, la costumbre y el derecho canónico obligaban a su majestad a requerir de Roma el pertinente breve papal para que excepcionalmente su santidad consintiera que el clero de Castilla fuese gravado. Los ministros reales tenían otra interpretación. No había, primero, exención estamental posible tratándose de regalías; segundo, ya que el "crecimiento" era una mera subrrogación de los antecedentes servicios y para éstos había habido breve, era ocioso volver a pedir otro. Pero no terminaba aquí el discurso clerical. En el punto del precio razonaron como ya en la junta se había hecho: el "crecimiento" de la sal, nunca mejor dicho, por cuanto excedía el precio natural y justo era pura y simple imposición, la cual se había introducido sin consentimiento, y por consiguiente cabía resistirla. Las calles de Sevilla se llenaron en efecto de panfletos en este sentido; "cartelli con invito a sollevazione" aparecieron también cerca de Granada ${ }^{44}$.

Como en 1623 había sucedido, volvía el clero a tomar la iniciativa de la resistencia. Sin embargo ahora la situación era mucho más grave. Con Urbano VIII en la cátedra de San Pedro y un nuncio (Monti) en Madrid nada simpático con el condeduque, la causa de los canónigos sevillanos derivó en un conflicto de proporciones que han pasado casi por completo desapercibidas. Y aunque mi principal fuente de información al respecto la constituya la correspondencia de este nuncio con Roma ${ }^{45}$, el testimonio de gentes del Consejo de Estado o del de Castilla que sigilosamente le informaban de lo que sucedía dentro, permite aseverar que la crisis a punto estuvo también de precipitar un desencuentro entre Felipe IV، y Olivares. "Le dejo, le dejo...", se le oyó decir.

Y es que el asunto fue en verdad gravísimo, al margen de la extensión de las resistencias locales, bajos rendimientos de la recaudación, etc. Los tres canónigos sevillanos que habían comenzado la protesta fueron apresados, ordenándose al asistente de Sevilla su conducción a Madrid. A medio camino se les comunicó orden de destierro a los reinos de la Corona de Aragón. Sabedor el nuncio, contraatacó con la más pesada artillería; su majestad no tenía autoridad para desterrar a clérigos de sus reinos pues éstos no eran sus súbditos. El pronunciamiento, por supuesto, no era argu-

44 Relazioni degli Stati Europei lette al Senato dagli Ambasciatori Veneti, ed. de N. Barozzi y G. Berchet, Venezia, 1860, Serie I; II, p. 18.

${ }^{45}$ Archivio Segreto Vaticano, Nunciatura di Spagna, vol. 72. 
El sistema español en la época de los Austrias. El modelo político e institucional (1516-1659)

mento de ocasión; ya en 1623 se había escrito que "el Estado Eclesiástico destos Reynos no es menos de Vuestra Magestad que el seglar, y aunque Vuestra Magestad no tenga en él la jurisdicción” [...]. En otras palabras, si es que hicieran falta, el clero se tenía por ajeno a la potestad de su majestad católica; la república clerical obedecía el principado del papa de Roma, y sólo mediante su intercesión o intermediación podía el rey de Castilla, en esta u otra materia, tener autoridad sobre ella.

El nuncio vio a Felipe IV; habló también con Olivares. De la primera conversación sabemos que el representante papal no tuvo pelos en la lengua, advirtiendo a su majestad que lo que de su catolicidad se esperaba era justamente no ya el respeto, sino el eventual aumento de la inmunidad eclesiástica. El rey llamó a Olivares y le dijo que el nuncio "le había cargado mucho la conciencia" y que esperaba que éste se la descargase. Fue entonces cuando el conde-duque comentó la posibilidad de su renuncia.

No disipado el conflicto con los eclesiásticos, y a la vista del fiasco que el "crecimiento" estaba significando, estaba claro que lo que de momento se imponía era una marcha atrás. Pero tampoco podía ser tal como para repetir la situación que acababa de provocar tan gravísimo conflicto. Haciendo memoria podía decirse ahora que la gabela de la sal traía causa del bajo rendimiento de los servicios de millones; que estos bajos rendimientos eran imputables a la pésima administración que el reino hacía desde la Comisión; y que en resumidas cuentas, puesto que ya había fracasado un intento de penetrar por las malas en la Comisión (1630), sólo cabía intentarlo de nuevo por vías menos traumáticas.

La reforma de la Comisión debía hacerla el reino junto en cortes, en su calidad de plataforma desde la cual hacían las ciudades oír su voz, pues al cabo éstas, mediante el juego de los votos consultivos y decisivos, se reservaban en última instancia cuanto de interés para ellas pudiera ventilarse en aquel foro. Pues bien, si los ministros reales debían conformarse con aceptar la forma de ayuda que era tradicional, los servicios, lo que desde luego no consentirían es que éstos no rindieran lo que nominalmente se anunciaba; seguiría, pues, habiendo millones, pero su gestión administrativa sería radicalmente distinta.

Así las cosas se convocó a las ciudades de voto en Cortes para el día 7 de febrero (1632) en Madrid. La carta había llegado un par de semanas antes a los cabildos, y en ella se decía que aquella sesión tendría por principal objeto proceder a la jura del heredero de la corona, príncipe Baltasar-Carlos. Para tal ceremonia, se decía, sería conveniente que los procuradores acudieran con voto decisivo. Sólo se añadía a este motivo principal la muy vaga referencia a "otros asuntos de importancia". Y aunque en los cabildos debió de producir cierto nerviosismo la petición del voto decisivo, lo cierto es que finalmente todos acudieron a Madrid con tal clase de poder bajo el brazo.

Una vez reunidos los representantes de las ciudades oyeron del presidente que si bien era cierto que allí estaban para la ceremonia de la jura, también habían sido con- 
vocados para sacar a su majestad del atolladero en el que éste se había metido. Supieron también que deberían trabajar "día y noche" y ofrecer rápidamente solución a la situación presente, cosa que se tenía por de fácil realización, habida cuenta de que el poder decisivo con el que venían les habilitaba para echar adelante sin contar con las respectivas ciudades y cabildos. El secreto, el engaño quedaba así desvelado. Los procuradores se resistieron cuanto pudieron; desde el Consejo de la Cámara se amenazaba con que de no aceptar lo que se les pedía, contaba su majestad con pareceres de "teólogos y otras personas doctas y sabias" que le facultaban para disolver la asamblea, mandarles de vuelta a sus ciudades e imponer lo que tuviera a bien con el solo visto bueno de su Consejo.

¿Y qué era lo que se pedía de las Cortes?. Pues como el tiempo apremiaba no había lugar más que para la restauración de los servicios suspendidos en 1631. Esto en lo cuantitativo. Pero nada se hubiera solucionado si estos mismos millones volvían a pasar por las manos de siempre. Áquí justamente radicaba la ruptura. A fines de julio de 1632 había ya "nuevos millones". La novedad no radicaba en las especies sobre las que caían sino en los modos de recaudación. Dicho en pocas palabras, las Cortes se habían visto obligadas a aceptar serios recortes tanto en las atribuciones de la Comisión como en las de las juntas locales. Allí entraban ministros reales cuando aquéllo había sido hasta el momento un reducto del reino; aquí se inauguraban prácticas comisariales de control también inéditas.

La ruptura con los usos del pasado era en efecto tan radical que los cabildos ciudadanos no tragaron sin más. Montaron un boicot recaudatorio que hizo que las recaudaciones de aquel año fueran las más bajas de todo el siglo XVII ${ }^{46}$. En su auxilio acudió inesperadamente otra vez la clerecía. Como el conflicto de los capitulares sevillanos no había concluido del todo, ni el nuncio ni el papa estaban dispuestos a pasar la mínima ofensa que se les hiciere. Así que cuando a fines de julio se publicaron los "nuevos millones", como no había breve papal para la contribución eclesiástica -aunque los ministros reales argumentaban que seguían vigentes los anteriores-, en muchos lugares se publicó la cessatio a diuinis y el "entredicho" para quienes tuvieran algo que ver con los servicios en cuestión. Como respuesta, en Sevilla, por ejemplo, la audiencia desterró al juez eclesiástico responsable de la censura.

En conflictos de esta naturaleza era siempre el poder secular el que tenía todas las de perder. El conde de Castrillo, que era quien andaba detrás de todo el tinglado, acabó por ofrecer marcha atrás en el conflicto con los cabildos ciudadanos. Los servicios de millones volvían a ser administrados por los juzgados locales, si bien bajo el control -no siempre fácil- de una Comisión en la que los ministros reales sí habían

46 J.I. Andrés Ucendo, "El servicio de millones...", p. 46. 
logrado mantenerse. Crecieron las recaudaciones, que fueron máximas entre 1633 y $1640^{47}$. Lo hicieron así quizá porque la única manera de hacer subir el rendimiento era extendiendo el mecanismo de las sisas a cuanto producto se pusiera por delante. Buena falta hacía de todos modos ya que la guerra con Francia iba a imponer a la Monarquía Católica cargas de toda suerte, y de las todavía no vistas.

Estas cargas no deben reducirse al mero esfuerzo fiscal, por importante que éste hubiera sido. Si la guerra contra los Habsburgo de Madrid obligó a la monarquía de Luis XIII a ensayar mecanismos administrativos de los que hasta la fecha no había hecho más que un uso episódico, también aquí el aparato del gobierno se vio obligado a experimentar notables alteraciones. El gobierno por juntas fue una de éstas. Nos suena familiar. De mi particular cosecha quisiera añadir ahora algo sobre la llamada Junta de Ejecución, a la que puede atribuirse una ubicación en la cúspide del sistema.

El apelativo es harto expresivo de lo que en una coyuntura como la de 1635 se quería decir con él. Partamos, para entendernos, de la constatación de una situación inicial cual era la de "falta de ejecución"; una situación a cada paso denunciada, según la cual por mucho que unas determinadas instancias de la administración hubieran decidido que algo debía hacerse, lo que fuere, a la postre o no se hacía o se hacía tarde y mal. "El fin del gobierno es la execución" -se decía; o: "propio de los reyes es mandar y de los ministros ejecutar". Estaba claro. La ejecución era la materialización de los actos de gobierno y éstos, a su vez, expresión de mandatos superiores. De poco servía que su majestad o sus ministros mandaran si estos deseos no tenían ejecución.

Así se describía a la tal Junta en una relación contemporánea ${ }^{48}$ :

La primera Junta que entre todos es la más principal por la dignidad, y más estimada por la autoridad de execución de la qual era secretario D. Fernando Ruíz de Contreras. En esta se trata todo lo que mira al bien universal de la Monarquía. Tiene tanta preeminençia a todo los Consejos y Tribunales que sus decretos no dependen de otra jurisdición que de la suia propia, y por esto es su nombre el de execución, porque quanto determina con sola participación del Rey (que nunca lo contradice) inmeditamante se executa.

$Y$ porque en esta junta efetibamente se tratan y se concluien todas las materias de estado tanto de guerra quanto de paz, fue necesario repartirse el peso en otras dos juntas, siéndole insoportable a una sola. De una fue secretario Juan García de Avila Muñoz y de otra Pedro Coloma. Los ministros eran treinta sacados a eleción del Conde de todos los Tribunales. (Estas tres juntas parecían emular el más sublime misterio de nuestra fee, siendo una en su sustancia y tres en personas). No se exercitaban nunca sino en el quarto del Conde, que era el primer móbil de aquel cielo al qual después del movimiento general y natural daba también el bigor.

${ }^{47}$ Ibid.

48 B.N., Mss., 8.175. 
Y el texto que sigue da cuenta más derecha de cómo se trabajaba:

En la Junta de la Execución se trata de todas materias: su despacho es brevísimo, con grandísimo alivio de los pretendientes; porque no corre aquí aquel embarazo de tantas formalidades y circunstancias de consultas, subidas, baxadas, pérdidas de consultas, réplicas, informaciones, etc., como lo hay en todos los demás tribunales, consiguiéndose aquí todo en un día; porque se executa y tiene esto por cosa muy acertada al servicio del Rey, cuya autoridad no ha de ser menor que la de otros reyes y príncipes, que no son atenidos a ninguna de las formalidades susodi$\operatorname{chas}^{49}$.

Al parecer la Junta, ignorada por lo demás en un reciente monografía sobre estos organismos ${ }^{50}$, aceleraba el proceso administrativo que en manos de los consejos y tribunales ordinarios se antojaba entonces difícilmente tolerable a causa de su lentitud. Lo que una situación como la inaugurada en 1635 precisaba era justamente algo como esto, inicialmente creado para atender a la coyuntura bélica -de ahí que John H. Elliott la haya calificado como "small war cabinet"-, pero que al poco tocaba "todas materias". El circuito podía darse por cerrado gracias a la Junta de Competencias ${ }^{51}$. Así se la describía:

Entre la inmensidad de tantos Consejos y Juntas, en que muchas veçes se tratauan unos mismos negocios que mirándolos a diuersas luces engendraban contrariedad de pareçeres, de modo que mientras más se contrataban tanto más se dilataban las expediciones, con notable perjuicio de los interesados, el Conde (que miraba a lleuar el agua al molino que sin cansarse jamás molía toda la suerte de granos), formó una Junta que llamó de Competencias, en que se bintilaban todas las materias en cuia decisión se conpetía, para que hecha primero la debida consideración de la contrariedad de pareçeres, esta gran Junta diese con suprema autoridad inapelable sentencia.

En el fondo la intención de esta junta volvía a ser próxima a la de arriba: no podía permitirse que conflictos de competencia impidiesen la rápida expedición de los negocios, y por consiguiente se hacía necesario atribuir con "suprema autoridad inapelable" cada asunto a la sede que más conviniere a los intereses en juego.

Obviamente, procedimientos como los referidos habrían de levantar las esperables contradicciones entre el aparato consiliar, que se veía rebajado, lateralizado o sen-

49 A. Rodríguez Villa, La Corte y la Monarquía de Espä̃a en 1636 y 1637, Madrid, 1886, p. 75.

${ }^{50}$ D.M. Sánchez, El deber de consejo en el estado moderno. Las juntas “ad hoc" en España (14711665), Madrid, 1993. Adviértase què el "deber de consejo" se canalizaba no a través de las juntas sino de los consejos. El despiste es mayúsculo.

${ }^{51}$ B. Cárceles de Gea, "La Junta de Competencias durante el reinado de Felipe IV. Un proyecto institucional en la Monarquía hispana", Critica Storica. Bolletino A.S.E., II (2), 1988, pp. 317-38. 
cillamente superado por esta clase de organismos, absolutamente ajenos a la tradición político-administrativa de Castilla. Aquí radicaría, como es sabido, uno de los focos que después de enero de 1643 más habría de levantar su voz contra Olivares; lamentablemente para el historiador, todo este supuesto malestar tiene que ser intuido para los antecedentes.

Pero no iba a ser sólo en estas altas esferas del gobierno donde el año 1635 y sus consecuencias inmediatas se dejaran notar. La presión sobre los procuradores de Cortes para que aprobasen lo que en efecto terminó por ser el servicio de los 9 millones en plata, volvió, como en 1632, a consistir en amenazar con la no convocatoria de la asamblea para lo sucesivo. Y los contribuyentes en general tampoco lo pasaron mucho mejor. Dos figuras fiscales se inauguraron ahora, no siendo desde luego las únicas; a saber, el papel sellado y las annatas de juros (medias, tercias, o como resultase). Ambas, sin embargo, serían de las que más iban a dar que hablar en el futuro.

Los juristas constituían una significativa porción de la población castellana, no tanto numérica sino por su importancia social. No cabía en ellos adscripción estamental concreta ya que titulares de juros lo eran las corporaciones eclesiásticas de toda clase, los mercaderes y tratantes de las ciudades, amén de la pequeña nobleza, titular o no de oficios municipales. Esta variopinta composición le hacía aparecer ante los ojos del gobierno como un segmento de la población al que había que tratar con guante de seda. Tradicionalmente los grupos rentistas, en Castilla y en otras partes, solían constituir una de las más firmes apoyaturas de los gobiernos, en tanto en cuanto su propia supervivencia dependía de la de aquéllos. Y así pudo haber sucedido aquí hasta que los juristas se vieron sistemáticamente atacados mediante la progresiva reducción del rendimiento (tipo de interés) de sus inversiones. Les sentó muy mal lo que Felipe III hizo con ellos mediante la Diputación del Medio General. Otro golpe sufrieron en 1621 al decretarse la reducción de sus títulos al 5\%. Volvió e pensarse en ellos en 1629-30 ("el quinto de los juros")52, aunque el arbitrio en cuestión acabó siendo sustituido por el "crecimiento" de la sal. Pero en 1635 no quedaba otra salida que retener una parte de las anualidades que el fisco pagaba a los juristas. Se tomó entonces el tercio, al año siguiente la mitad, y así hasta $1640^{53}$. No es posible desconocer el malestar que estos valimientos causaban a tan conspicuos miembros de la comunidad política; con la clerecía habían topado una vez más el conde-duque y sus ministros, de manera que no es casual que una mano eclesiástica anduviera detrás de cierto memorial escrito en nombre de los "juristas acreedores" que apareció en enero de 1641.

52 Elliott, The Count-Duke..., p. 417.

53 P. Toboso Sánchez, La deuda pública castellana durante el Antiguo Régimen (juros), Madrid, 1987, pp. 176-7. 
Pero otro tanto sucedió a propósito del papel sellado, cuya introducción ya se había sugerido también en 1629-30. Ahora la oposición volvía a articularse sobre bases muy similares a las de 1631, pues no en vano se trataba de otra regalía. Protestaron los clérigos y las provincias de gobierno "más privilegiado", i. e., las Vascongadas. Las oficinas del nuncio rechazaban el papel y en el norte se argumentaba que el asunto era "contrafuero". Mas lo que Olivares no podía prever era que se resistiera también dentro del propio gobierno, como en efecto sucedió al negarse también inicialmente a admitirlo los consejos de Órdenes y Aragón.

Así pues la guerra con Francia significó la neçesidad de apretar el acelerador administrativo y fiscal, allí alumbrando nuevas sedes desde las que se pretendía una mejor solución de los problemas, aquí introduciendo nuevas figuras fiscales en ámbitos no explotados y por lo mismo susceptibles de mejor rendimiento. Y no fue esto todo. A su vez, la necesidad de que la "ejecución" se extendiera también a los ámbitos de la administración provincial y de que los nuevos impuestos tuvieran debido cobro -lo que en concreto significaba una administración también nueva y ad hoc (Junta de Media Annata, del Papel Sellado)-, alentó la extensión de formas de jurisdicción comisarial que, en su caso, lo que hacían era suplantar las magistraturas ordinarias (regidores, corregidores) en quienes Olivares y sus criaturas no podían confiar el despliegue a pie de obra de su agresiva política. Obviamente, un circuito de agravios y su correspondiente feed-back-defensa- unió de una parte a juntas y comisarios y de la otra a consejos y magistraturas ordinarias en géneral. De nuevo habrá que esperar a enero de 1643 para poder observar su afloramiento documental.

Mal cariz estaban tomando las cosas cuando en 1640 hubo que afrontar los sucesos de Cataluña y Portugal. De inmediato (1641) se procedió a acuñar vellón, con lo que los precios alcanzaron el nivel más alto hasta entonces conocido. Se temía -refiere alguna crónica contemporánea- "gran desdicha y motín, porque se habla muy mal de rey y ministros”. Tan delicada debía de ser en efecto la situación que el gobierno no se atrevió entonces (1641 y 1642) a seguir decretando valimientos de la media annata de juros. Y lo más grave era que Felipe IV estaba=decidido a afrontar personalmente la restauración del "buen gobierno" en Cataluña; lo que significaba la apertura de un serio debate -similar al de 1635- respecto a la conveniencia o no de su salida. Esta, además, podía tener una influencia nada desdeñable sobre la posición del valido. De acuerdo con el testimonio del embajador imperial, conde de Grana, testigo de primera fila en aquellos días ${ }^{54}$, los términos del debate eran: a) si el rey debía salir o no; y b) quién quedaría en Madrid al frente del gobierno.

54 A. Domínguez Ortiz, Historia de la caída del conde-duque de Olivares (manuscrito del siglo XVII), Málaga, 1992, pp. 69 y ss. 
A diferencia de lo sucedido en 1635 , cuando la oposición a la salida del rey pareció un ejercicio retórico cuyo único sentido era precisamente servir de contrapunto a los partidarios del sí, la cuestión ahora se veía de otra manera. José González, por mandado del conde-duque, razonó "en derecho", como jurista que era, que su majestad no debía salir de Castilla. No es aventurado aseverar que usaría del tópico del pater familias para hacer ver que en aquellas circunstancias un abandono del "hogar" era de todo punto indeseable. Pudiera ser. Sin embargo, no era ésta la clase de argumentos que en el fondo manejaba Olivares y su fiel ministro -según el conde de Grana. Si el rey salía de Madrid, Olivares estaría obligado a seguirle, momento que la reina Isabel de Borbón utilizaría para socavar el entramado del gobierno del conde-duque en Madrid. Debe saberse, en efecto, que lo mismo que le había pasado a Lerma, la reina volvía a ser ahora el principal elemento de oposición en la corte al valimiento del conde-duque. Para salvar el cuello, Olivares debía convencer a Felipe IV de que no saliera de Madrid, pues si, además, la operación fracasaba, el valido podía ser acusado de haber conducido a su señor al más espantoso ridículo.

Pues bien: Felipe IV hizo su “jornada”, Isabel de Borbón quedó como regente, Olivares siguió a su rey y la campaña terminó en un estrepitoso fracaso. Pero vayamos por partes. Felipe IV hizo su jornada a pesar de las maniobras dilatorias de Olivares que no se resignaba a que ni él ni el rey abandonaran la corte; el rey, de hecho, dio vueltas y más vueltas en los primeros días del viaje "entretenido" por su ministro. En su papel de regente Isabel demostró unas dotes de gobierno que a Olivares debieron causar conmoción. En particular, a ella y al conde de Castrillo -pareja que ya había funcionado en 1632- cabe imputar la vuelta del vellón a los valores anteriores al decreto de 1641, con lo que aquellos altos precios se derrumbaron de un plumazo a partir del 15 de septiembre de 1642. Lo más grueso de la intranquilidad social quedaba así desactivado ${ }^{55}$. La campaña de 1642 fue un completo desastre, no quedando a Olivares más remedio que postrarse de rodillas ante Felipe IV.

La vuelta a Madrid fue tormentosa para el conde-duque, quien a su paso por Alcalá de Henares resultó apedreado. Pero lo peor estaba por venir, ya que la reina Isabel estaba ahora autorizada para contar a su marido lo que antes hubiera caído en saco roto. Inicialmente parecía, sin embargo, que nada hubiera sucedido entre rey y valido. Olivares se dedicó por ejemplo a reestructurar la Junta de Ejecución dividiéndola en salas. Parece que el punto de la definitiva ruptura se produjo con ocasión de los nombramientos para la casa del príncipe. Aquí Felipe IV no transigió.

55 "En 15 del dicho se pregonó la vaja de la moneda de vellón [...] vajáronse luego las mercaderías a menos de la mitad"; Memorias de Sevilla, p. 102. 
Tiene razón John H. Elliott cuando sugiere que la salida de Olivares de la escena política constituyó una suerte de mal menor que evitó otro mayor, a saber, que la explosiva situación de Castilla por aquellos días cońndujera a hechos como los que también por aquellos días acontecían en París o Londres, y de los cuales había cumplida información en Madrid ${ }^{56}$. Nada mejor para calibrar la importancia de esta incruenta revolución que atender a lo que trás ella vino, es decir, a lo que de no haberse producido la salida de Olivares pudiera haber constituido un "programa" de alcance tal vez revolucionario.

Aunque nos queda mucho por conocer de estos meses inmediatos, la caída del valido condujo al menos a tomar las decisiones siguientes; a) el ejercicio de las juntas quedó suspendido y los consejos restaurados en todas sus competencias; b) en similar línea, las jurisdicciones comisariales fueron restringidas, tomando su lugar la ordinaria -fundamentalmente en materia de administración fiscal; c) la venalidad de oficios fue sacrificada en aras de una "justicia distributiva" que ahora se decía debía imperar. Hubo más: Felipe IV, a la vista de lo que en el pasado había hecho, mandó formar una Junta de Conciencia para conocer si su proceder pasado le había hecho abandonar sus obligaciones de "padre de familia". A Tomás de Aguilar encargó que contara lo que desde 1621 le habían pagado sus súbditos, habiéndole entrado también escrúpulo al respecto. En suma, todo un programa de "desarme" fiscal y administrativo recorrió el aparal $\&$ del gobierno en aquellos meses inmediatos. Y todavía seguiría hasta llegar a dar con lo que constituía la más ansiada política: la del "alivio".

La palabra había aparecido sin duda en otras ocasiones, pero como "desempeño" hacía cuarenta años estaba ahora en su sazón. Lo que Castilla necesitaba era eso y sólo eso: alivio. Éste era precisamente uno de los puntos que iban a tratarse en las Cortes que se abrirían en 1646. Y en la carta que el presidente don Juan Chumacero envió a las ciudades se daban algunas pistas; puesto que no se podía "hescusar el grabamen en la sustançia", se trataría de hacerlo en la forma. Esta forma se insinuaba también: era preciso reducirlo todo -todos los impuestos- a "un jénero o a una obligación" 57 . Hubo quien tomó buena nota del mensaje del señor presidente, en concreto Jacinto de Alcázar Arriaza que entonces publicó sus Medios Políticos para el remedio vnico, y vnibersal de España... ${ }^{58}$ La obrita, que no suele merecer más que un par de líneas en cualquier antología o estudio de nuestros arbitristas, causó en la época una conmoción que

56 J.H. Elliott, "Una sociedad no revolucionaria: Castilla en la década de 1640", 1640: la Monarquía Hispánica en Crisis, Barcelona, 1992, pp. 102-22.

${ }^{57}$ Actas de las Juntas del Reino de Galicia. 1642-1647, vol. V; edición realizada bajo la dirección del prof. A. Eiras Roel, Santiago, 1997, pp. 529 y 638.

58 B.N., Mss. 5.801 (incompleto en su parte final). 
no he visto consignada en parte alguna. Vale la pena intentar encontrar las razones. La obra era cómoda de leer por lo breve. Había sido impresa por el "Impressor del Reyno" y compuesta "por mano del reyno junto en cortes"; con el encabezamiento "El reyno junto en cortes" empezaba también Alcázar su prólogo, de manera que no se sabía muy bien si aquello era obra particular o de "el reyno junto en cortes", puesto que también, como si de acuerdos de Cortes se tratara, concluía además con unos "capítulos".

El remedio de Alcázar consistía en agregar a los "antiguos pechos Reales" ("que han de quedar por reconocimiento de la Nobleza"), "vna general sola, y en parte voluntaria alcauala" en lugar de la multiplicidad de tributos existentes. Pero lo mejor del caso era que bien hecho el reparto, y conocidos por pueblos e individuos lo que a cada uno tocaría, lo pedirían por "conveniencia propia" unos y otros, de manera que las viejas contribuciones podrían ser levantadas.

Pues bien: lo que era arbitrio, proyecto, sin duda debido a la reiterada mención y patrocinio de "el reyno junto en Cortes" se tomó por acuerdo de él; en algún lugar dejaron de pagarse los millones y otras imposiciones a la espera de que alguien acudiera a cobrar la nueva alcabala ${ }^{59}$.

Lo referido no pasaría de mera anécdota si no se conociera además que las circunstancias por las que ya entonces y en meses inmediatos andaba inmersa Castilla no eran ni mucho menos para ser tomadas a broma. En la primavera de 1647, en el seno de una coyuntura agraria francamente adversa, estallaba una copiosa serie de motines en Andalucía ${ }^{60}$. Pero la secuencia de los hechos no permite su catalogación como puros y simples motines de subsistencias. De acuerdo con relatos cronísticos contemporáneos, las lluvias llegaron puntualmente a Andalucía en aquel año de 1647; no fue hasta el 9 de mayo cuando se volvieron torrenciales y extemporáneas, de manera que "los trigos se pasmaron y se enjugó el grano de forma que todo se quedó en paja". Pero desde enero se había desatado ya la inquietud en Lucena, Ardales y otros puntos, con quema del papel sellado, registros de las alcabalas, etc. Sobre estos hechos cayó la carestía, y sobre todo las maniobras de acaparación que agravaron la intensidad de la crisis. Lo sucedido en Granada al año siguiente confirmó la gravedad de la situación. Por fin la revuelta entraba en Castilla, y lo hacía al tiempo en que además rebrotaba en Nápoles.

Había que actuar. En auxilio del gobierno de Madrid llegó en enero de 1647 la noticia de que las Provincias Unidas parecían inclinadas a suspender las hostilidades

59 A. Domínguez Ortiz, "La comisión de D. Luis Gudiel para la venta de baldíos de Andalucía", Congreso de Historia Rural. Siglos XV-XIX, Madrid, 1981, pp. 511-22.

${ }^{60}$ Del mismo, Alteraciones andaluzas, Madrid, 1973. 
en pos de una paz. Sin perder un minuto (marzo) ordenaba Felipe IV mediante decreto "se procure aliviar a los vasallos [...] sin diminución de los tributos". La tarea no era fácil; pero a la vista de los malos aires que soplaban desde el sur, no obstante compensados por los buenos del norte, existía cierto margen de maniobra. Ésta consistió en suspender el pago de las consignaciones a los banqueros (octubre), con lo que obviamente el gobierno obtenía un tiempo precioso para afrontar la situación doméstica. Buena falta le hacía. Hubo miedo en 1648, e incluso después, a la vista de lo que había sucedido. Por lo pronto, mientras Andalucía seguía ardiendo y se hablaba ya sin recato de una eventual "pérdida de Reynos", Felipe IV anunciaba en Cortes (agosto) el esperado alivio. Al mismo tiempo el Consejo de Estado veía si convenía ratificar o no el perdón que el de Castilla había sugerido para los revoltosos de Granada. Desde aquél, desde el Consejo de Estado ${ }^{61}$, si bien se afirmaba que "la disimulación de qualquier soleuazión o amago della, por pequeña que sea, en los Reynos y vasallos de V.M. es muy peligrosa y digna de toda demostración y castigo por los malos exemplares que produze", ahora mismo,

por la mala constituzión de los tiempos se debe ceder y disimular mucho por no encontrar con mayores inconvenientes, si bien el accidente pasado se ha entendido tubo su principio de la necessidad y hambre que aquellos naturales padezían, y ya fuese por achaque de interés o mala providencia de los que gobernaban (como se dize), haze mudar de specie su delito, pues el comer es de los casos en que los pueblos siempre han librado sus mayores disculpas, y de las que suelen exceptuarse.

Y se decía más: de no ofrecerse ahora el perdón podría sobrevenir la "desesperación" que pudiera obligarles a "alguna temeraria resoluzión”, cosa que convenía evitar de todo punto, debiendo hacerse la publicación de manera inmėdiata.

La efectiva rebaja de la presión fiscal efectuada en el verano de 1648 redujo sin duda las tensiones que entonces pesaban sobre la sociedad castellana y que habían tenido a Andalucía como principal escenario. Pero no las eliminaron totalmente. En 1652 volverían a reproducirse, y de nuevo sobre un esquema muy similar al de 1647 8, esto es, confluencia de cortas cosechas con alzas en la presión fiscal.

Las cosas se desarrollaron más o menos así. El año 1651 fue un mal año agrícola; la cosecha había sufrido una reducción del $23,88 \%$ sobre la tendencia del período (1600-1665), y los precios subieron -también sobre la tendencia del período- entre un 90 y un $93 \%$, según unas u otras cotizaciones ${ }^{62}$. Era una subida artificial, pues la

${ }^{61}$ AGS, E, leg. 2.668.

${ }^{62}$ Los datos sobre precios y cosechas proceden de P. Ponsot, Atlas de historia económica de la baja Andalucía: siglos XVI-XIX, Sevilla, 1986. 
cosecha de 1650 había sido el doble de mala y sin embargo los precios habían subido sólo el 58 o 60\%. ¿Qué estaba pasando?. Pues lo que otras veces, incluido 1647-8.

Venía tratándose la conveniencia de recoger todo el vellón circulante, ya que una de las trabas más serias para la contratación de asientos era justamente el premio de la conversión vellón/plata. El asunto se conocía por el público en general, y la medida obviamente favorecía a unos y perjudicaba a otros, creando la tensión imaginable en los operadores económicos. 'El 20 de octubre el Consejo de Castilla daba cuenta de que a causa del proyecto de consumo del vellón

se habían alterado los precios en los principales lugares de Andalucía, y en ocasión que por la esterilidad los granos y mantenimientos necesarios tenían tan excesivo valor, que si se le aumentase esta causa más podríase temer disturbios en los pueblos, es de parecer [...] no conviene tratar de executarla [el consumo] hasta que el estado de las cosas tenga diferente disposición ${ }^{63}$.

¿Y por qué se alteraban los precios?. Pues por la sencilla razón de que los granos no salían al mercado -como en 1647- mientras el panorama monetario no pareciera tranquilo y despejado. A pesar de no haberse producido la temida -por algunosrecogida del vellón, los efectos fueron los previstos y aún peores pues otra medida, monetaria también, los precipitó. Había que aprovechar la convulsa situación interna de Francia para intentar un golpe sobre Cataluña en 1652. Y no había un maravedí libre hasta 1653 , de manera que en vez de consumir el vellón se reselló el que había para volverlo al valor previo a la baja de 15 de septiembre de 1642. Los efectos se conocen: el motín de la feria en Sevilla. Debe saberse también que para neutralizarlo se vio obligado el presidente de la audiencia a decretar la consabida baja, una atribución regaliana que sin embargo apaciguó los ánimos y que Felipe IV no tuvo más remedio que confirmar. Esto volvía a reducir a cero las disponibilidades financieras, de manera que se decretó -como en 1647- otra suspensión de consignaciones. Ese mismo año Barcelona caía en manos de las tropas de Felipe IV.

En fin, que lejos de aceptar sin más una tranquila situación socio-política en las décadas centrales de nuestro siglo XVII, la investigación depara un panorama algo más convulso, del cual me atrevería a destacar que si no llegó a los extremos a los que lo hizo en Francia o Inglaterra fue porque aquí, a la mínima ocasión, el gobierno de Madrid dio marcha atrás en todas aquellas medidas capaces de crear situaciones de tensión. Pasó también en 1640 con el Donativo general por fuegos. La impresión es que la Corte, ya nerviosa por lo que acontecía en su periferia, en Francia y en Inglaterra, extremos todos sobre los cuales la información era abundante, como prueba la

63 A. Domínguez Ortiz, Política y hacienda de Felipe IV, Madrid, 1960, pp. 263-6. 
multitud de Noticias y otros especímenes del género que guardan las Bibliotecas Nacional y Real, no podía permitirse el lujo de ver cómo la revuelta explotaba también de puertas adentro. De 1643 a 1652 la Monarquía se movió dentro de una sistemática marcha atrás cuyo resultado fue que entre 1648 y 1659 (Westfalia y Pirineos) se fue al traste su posición hegemónica en el sistema europeo de estados. 